\title{
EVALUASI PERAN JENIS IKAN DALAM PEMANFAATAN SUMBER DAYA PAKAN DAN RUANG DI WADUK IR. H. DJUANDA, JAWA BARAT
}

\author{
Didik Wahju Hendro Tjahjo, Sri Endah Purnamaningtyas, dan Astri Suryandari \\ Peneliti pada Loka Riset Pemacuan Stok Ikan, Jatiluhur-Purwakarta \\ Teregistrasi I tanggal: 27 Mei 2009; Diterima setelah perbaikan tanggai: 8 Juni 2009; \\ Disetujui terbit tanggal: 18 Juni 2009
}

\begin{abstract}
ABSTRAK
Waduk ir. H. Djuanda mempunyai potensi pengembangan budi daya ikan yang tinggi, maka pertumbuhan budi daya tersebut berkembang sangat pesat. Perkembangan yang pesat tersebut sangat berdampak pada penurunan kualitas air baik untuk kehidupan dan perkembangan ikan dan organisme makanannya. Sehingga sebagian besar jenis ikan asil Sungai Citarum sudah sangat jarang ditemukan bahkan beberapa jenis telah punah di perairan ini. Tujuan penelitian adalah untuk mengevaluasi peran dan interaksi aniar jenis ikan yang tertangkap dalam memanfaatkan sumber daya pakan dan ruang di Waduk Ir. H. Djuanda. Penelitian ini dilakukan setiap bulan pada tahun 2006. Pengamatan ini dilakukan dengan metode stratifikasi dengan enam titik stasiun pengamatan. Ânalisis data meliputi kebiasaan makan, tingkat trofik, luas relung, dan interaksi dalam pemanfaatan sumber daya terhadap jenis ikan baik tehadap makanan maupun ruang. Hasil analisis kebiasaan makan, luas relung, dan interaksi antar jenis ikan menunjukkan bahwa peran sumber daya makanan di perairan ini sudah cukup lengkap. Sedangkan berdasarkan pada analisis pemanfaatan ruang secara horisontal menunjukkan bahwa daerah dam atau genangan utama kurang mampu dimanfaatkan secara optimal. Hal tersebut berarti bahwa penebaran jenis ikan dalam rangka mengisi relung ekologi yang kosong tidak diperlukan, tetapi penebaran ikan tersebut diperlukan dalam rangka meningkatkan efektivitas dan efisiensi dalam memanfaatkan sumber daya yang tersedia khuşusnya ruang. Oleh karena itu, dalam upaya untuk efektivitas dan efisiensi nemanfaatan sumber daya yang tersedia, khususnya di daerah genangan utama, periu dilakukan penebaran jenis ikan yang bersifat peiajis dan pemakan plankton, yaitu ikan patin (Pangasionodon hypopthalmus) dan bandeng (Chanos chanos).
\end{abstract}

KATAKUNCl: tingkat trofik, kebiasaan makanan, distribusi, luas relung, kompetisi

ABSTRACT: Evaluation of fish species role in utilization of food and space resource in Ir. $H$. Djuanda Reservoir, West Java. By: Didik Wahju Hendro Tjahjo, Sri Endah Purnamaningtyas, and Astri Suryandari

Ir. H. Djuanda Reservoir has highly potential development for fish culture, and so the growth of the culture expands very fast. The development might give an impact to the water quality degradation as well as to life or growth of fish and its food organism. So that most of indegeneus species of Citarum River were found very rare even some species have extincted. The study aims to evaluate role and interaction between fish species in exploiting available resources in Ir. H. Djuanda Reservoir. The study was conducted in ir. H. Djuanda Reservoir in 2006. Those observations were using conducted stratified method at 6 stations. Evaluations were done using the analysis of food habit, trophic levels, niche breadth, and fish species interaction. Result of food habit, niche breadth, and fish species interaction indicated that role of fish in exploiting food resources in this water were sufficient. While pursuant to analysis of exploiting of space in horizontal indicated that the dam area or main inundation was not exploited optimaly. It means that the fish stocking for the agenda of filling the empty ecology niche not needed, but the fish stocking is still needed for the agenda of improving effectiveness and efficiency in exploiting the available resources, specially the utilization of maximum space. Therefore, in the effort of effectiveness and efficiency of exploiting to the available resources, especially in the main inundation, would be needed to do fishes stockings which have the character of pelagic and planktivores, such as Siam catfish (Pangasionodon hypopthalmus) and milkfish (Chanos chanos).

KEYWORDS: trophic level, food habit, distribution, niche breadth, competition

\section{PENDAHULUAN}

Waduk ir. H. Djuanda dapat digunakan sebagai lahan alternatif budi daya ikan dalam kantong jaring apung, dan ternyata pertumbuhan kantong jaring apung tersebut berkembang sangat pesat. Pada tahun 2005, jumlah kantong jaring apung 4.577 unit dan pada tahun 2006 sudah mencapai 15.000 unit, walaupun kantong jaring apung yang diizinkan berdasarkan pada Surat Keputusan Bupati Purwakarta No.06/2000 
adalah 2.100 unit. Perkembangan yang pesat tersebut berdampak nyata terhadap penurunan kualitas air baik untuk kehidupan dan perkembangan ikan dan organisme makanannya.

Penurunan kualitas air di Waduk Ir. H. Djuanda tersebut semakin nyata, sebagai akibat posisi waduk tersebut di bagian paling hilir di antara tiga waduk kaskade di Sungai Citarum, di mana waduk di bagian hulunya (Waduk Cirata dan Saguling) juga dimanfaatkan untuk kantong jaring apung. Tekanan tersebut mendorong perubahan struktur jenis ikan dalam komunitas ikan tersebut. Beberapa jenis ikan yang mampu menyesuaikan terhadap perubahan lingkungan tersebut cenderung terus tumbuh dan berkembang, sedangkan jenis ikan yang tidak mampu akan tertekan perkembangannya dan bahkan terancam punah. Hal ini dapat dilihat dari perubahan komposisi jenis ikan hasil tangkapan di Waduk Ir. H. Djuanda pada tahun 1982-1983, yaitu ikan tagih (Mystus nemurus), jambal (Pangasius pangasius), tawes (Barbonymus gonionotus), hampal (Hampala macrolepidota), kebogerang ( $M$. negriceps), nila (Oreochromis niloticus), lalawak (B. bramoides), genggehek (Mystacoleucus marginatus), gabus (Channa striata), dan belida (Notopterus chitala) (Krismono et al., 1983). Komposisi tersebut relatif sama untuk tahun 1982-1988 (Purnamaningtyas, 1994). Pada tahun 1993, jenis ikan tersebut mengalami penambahan dua jenis, yaitu ikan betutu (Oxyeleotris marmorata) dan kaca (Parambasis siamensis) (Tjahjo \& Umar, 1994). Pada tahun 2003-2004, komposisi jenis ikan sudah sangat berubah, yaitu ikan oscar (Amphilophus citrinellus), kongo (Parachromis managuensis), bandeng (Chanos chanos), nila, patin, dan kebogerang (Kartamihardja, 2007). Perubahan komunitas ikan yang sangat nyata tersebut diduga akan bepengaruh terhadap belum optimalnya pemanfaatan sumber daya makanan yang tersedia oleh komunitas ikan yang ada. Oleh karena itu, suatu analisis telah dilakukan terhadap peran dan interaksi antar jenis ikan yang berkaitan dengan pemanfaatan sumber daya makanan dan ruang di Waduk Ir. $\mathrm{H}$. Djuanda.

\section{BAHAN DAN METODE}

Penelitian telah dilakukan di Waduk Ir. H. Djuanda, Jawa Barat pada tahun 2006. Pengumpulan data dilakukan pada bulan Maret, Mei, Agustus, Oktober dan Desember (mewakili musim dan dinamika penyebaran ikan) dengan menggunakan metode stratifikasi (stratified sampling method) (Nielsen \& Johnson, 1985). Titik pengambilan contoh ditentukan pada enam titik stasiun pengamatan yang mewakili daerah Alur Citarum, Alur Cilalawi, dan genangan utama, dan stasiun pengamatan tersebut antara lain 1) Sodong, 2) Bojong-Jamaras, 3) Kerenceng, 4) DAM, 5) kantong jaring apung, dan (6) Ubrug (Gambar 1).

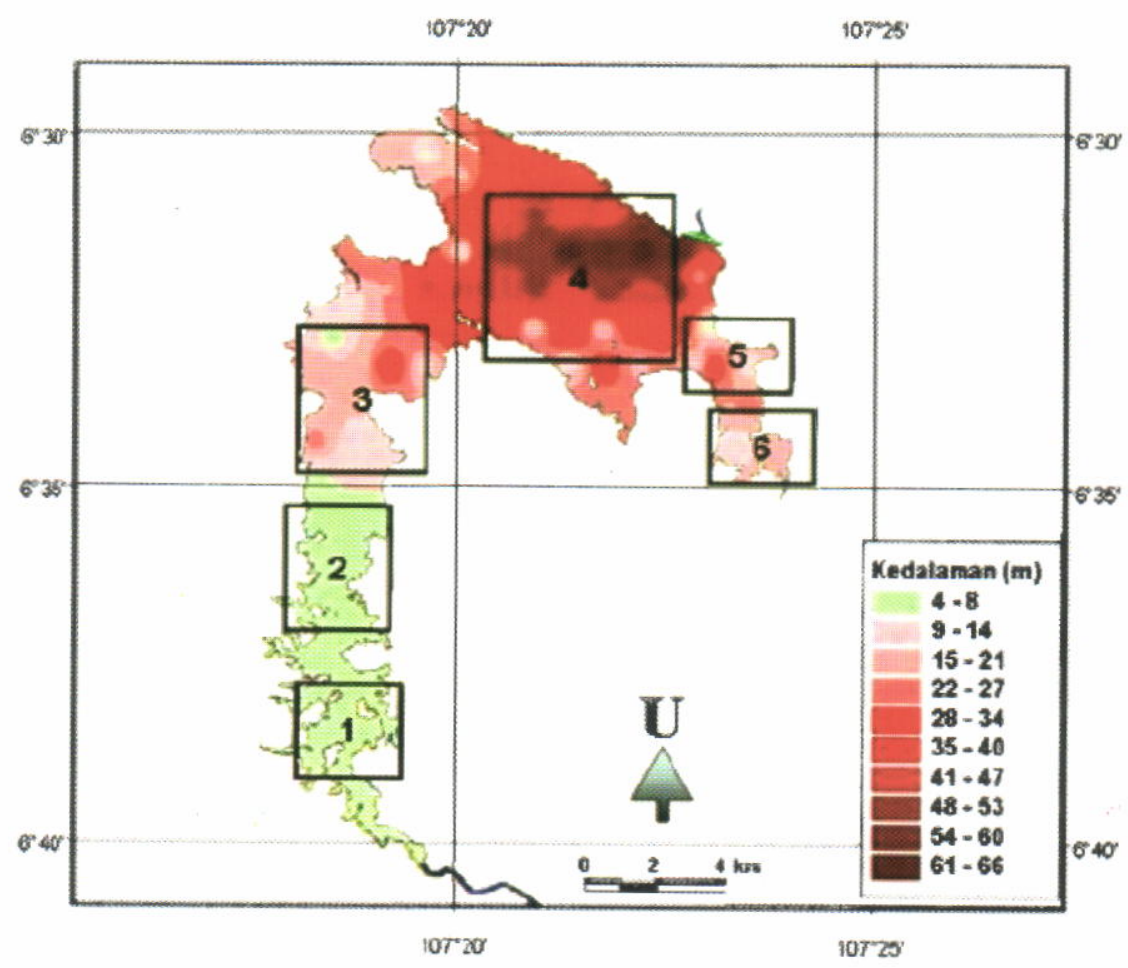

Gambar 1. Waduk Ir. H. Djuanda dan stasiun pengamatan.

Figure 1. Ir. H. Djuanda Reservoir and observation station. 
Pengambilan contoh ikan menggunakan jaring insang percobaan yang dipasang pada masing-masing stasiun pengamatan. Jaring insang percobaan yang digunakan menggunakan jaring monofilament berukuran mata jaring $1,1,5,2,2,5,3,3,5$, dan 4 inci. Ikan yang tertangkap diidentifikasi jenisnya, diukur panjang, dan bobotnya. Selanjutnya, ikan tersebut dibedah, diambil lambungnya dan dimasukkan dalam kantong plastik dan diawetkan dalam formalin $5 \%$ serta diberi label. Isi lambung ikan tersebut diamati di laboratorium Loka Riset Pemacuan Stok Ikan, Jatiluhur.

Indikator dalam pemanfaatan potensi sumber daya makanan untuk ikan menggunakan data kebiasaan makan, tingkat trofik, luas relung, dan interaksi dalam pemanfaatan sumber daya antar jenis ikan baik terhadap makanan maupun ruang. Hasil analisis akan memberikan informasi mengenai status pemanfaatan sumber daya makanan yang ada.

Kebiasaan makan menggunakan Indeks Preponderan (Preponderance Index), yaitu:

$\mathrm{I}_{\mathrm{i}}=\frac{\mathrm{V}_{\mathrm{i}} \times \mathrm{O}_{\mathrm{i}}}{\Sigma\left(\mathrm{V}_{\mathrm{i}} \times \mathrm{O}_{\mathrm{i}}\right)} \times 100 \%$

di mana:

$\begin{array}{ll}V_{i}= & \text { persentase volume satu kelompok } \\ & \text { makanan } \\ O_{i}= & \text { persentase frekuensi kejadian satu } \\ & \text { kelompok makanan } \\ O\left(V_{i} \times O_{i}\right)= & \text { jumlah } V_{i} \times O_{i} \text { dari semua kelompok } \\ \text { makanan }\end{array}$

Estimasi tingkat trofik jenis ikan dihitung dengan menggunakan rumus yang diuraikan oleh Mearns et al. dalam Caddy \& Sharp (1986), yaitu:

$$
T_{t}=1+\sum\left\{\frac{T_{t p} \times I_{p}}{100}\right\}
$$

di mana:

$T_{t}=$ tingkat trofik

$T_{t}=$ tingkat trofik kelompok makanan ke-p

$!^{t}=$ indeks preponderan kelompok makanan ke-p

Luas relung dilihat dari makanan atau ruang yang dimanfaatkan oleh ikan dan dihitung dengan menggunakan Indeks Levin (Hespenheide, 1975), yaitu:

$$
B_{j}=\left(\sum p_{i}^{2}\right)^{-1}
$$

di mana:

$$
\begin{aligned}
& \mathrm{B}_{\mathrm{i}}=\text { luas relung } \\
& \mathrm{p}_{\mathrm{i}}=\text { proposional kelompok makanan atau ruang } \\
& \text { ke-i yang dimanfaatkan oleh ikan ke-j }
\end{aligned}
$$

Interaksi antar jenis ikan dievaluasi berdasarkan pada makanan yang dikonsumsi oleh ikan dan ruang, serta dihitung dengan menggunakan jarak Euclidiean (Legendre \& Legendre, 1983; Ludwig \& Reynolds, 1988; Sokal \& Rohlf, 1995), dengan rumus sebagai berikut:

$$
D_{1}\left(x_{1}, x_{2}\right)=\sqrt{\sum_{i=1}^{n}\left(y_{i 1}-y_{i 2}\right)^{2}}
$$

di mana:

$$
\begin{array}{ll}
1 \text { dan } 2= & \text { indeks untuk individu } \\
\mathrm{x} & =\text { jenis ikan } \\
\mathrm{y} & =\text { kelempok makanan yang dikonsumsi } \\
& \text { ikan atau ruang } \\
& =\text { jenis kelompok makanan atau ruang } \\
& \text { bervariasi dari } 1 \text { sampai } n
\end{array}
$$

\section{HASIL DAN BAHASAN}

Jenis ikan yang tertangkap adalah ikan nilem (Osteochilus hasselti), patin, nila, kaca, benteur (Puntius binotatus), hampal, oscar, kebogerang, goldsom (Amphilophus alfari), kepiat (Thynnichthys thynnoides), bandeng, tawes, lalawak, sepat (Trichogaster pectoralis), tagih, kongo, dan lempuk (Ompok bimaculatus). Jenis-jenis ikan tersebut kecuali ikan tawes, lalawak, dan lempuk, dianalisis isi perutnya untuk mengetahui kebiasaan makanan komunitas ikan tersebut (Tabel 1).

Hasil analisis kebiasaan makanan menunjukkan bahwa ikan kaca yang berperan sebagai ikan herbivora (nilai tingkat trofik kurang dari 2,25) (Tabel 1 dan Gambar 2), dengan fitoplankton sebagai makanan utama, dan makanan pelengkapnya detritus dan zooplankton. Kebiasaan makan tersebut berbeda dengan kebiasaan makan ikan kaca di Waduk Darma (Tjahjo et al., 2001; Tjahjo, 2004). Kelompok ikan omnivora yang suka tumbuhan (nilai tingkat trofiknya berkisar 2,25-2,50) terdiri atas ikan beunter, patin, dan nila, yang mana ketiga jenis ikan tersebut mempunyai makanan utamanya hanya fitoplankton, kecuali benteur mempunyai makanan utama fitoplankton dan detritus. Makanan pelengkap untuk ikan benteur 
Tabel 1. Kebiasaan makanan beberapa jenis ikan di Waduk Ir. H. Djuanda

Table 1. Food habit of some fishes in Ir. H. Djuanda Reservoir

\begin{tabular}{|c|c|c|c|c|c|c|c|c|c|c|c|}
\hline \multirow[b]{2}{*}{ No. } & \multirow[b]{2}{*}{$\begin{array}{l}\text { Jenis ikan/ } \\
\text { Fish species }\end{array}$} & \multicolumn{9}{|c|}{ Kelompok makanan/Food groups (\%) } & \multirow{2}{*}{$\begin{array}{c}\text { Tingkat } \\
\text { trofik/ } \\
\text { Trophic } \\
\text { level } \\
\end{array}$} \\
\hline & & $\begin{array}{l}\text { Phyto- } \\
\text { plankton }\end{array}$ & $\begin{array}{l}\text { Macro- } \\
\text { phyta }\end{array}$ & Detritus & $\begin{array}{l}\text { Zoo- } \\
\text { plankton }\end{array}$ & $\begin{array}{l}\text { Insct } \\
\text { larva }\end{array}$ & Worm & Moliusca & Inset & Fish & \\
\hline & $\begin{array}{l}\text { Nila } \\
\text { (Oreochromis niloticus) }\end{array}$ & 74,6 & 18,8 & 6,2 & 0,5 & . & & & & & 2 \\
\hline 2. & $\begin{array}{l}\text { Kaca } \\
\text { (Parambasis siamensis) }\end{array}$ & 94,5 & 0 & & 5,4 & & & & & & 2,05 \\
\hline 3. & $\begin{array}{l}\text { Beunter } \\
\text { (Puntius binotatus) }\end{array}$ & 49 & 4 & 26 & & 21 & & & & & 2,21 \\
\hline 4. & $\begin{array}{l}\text { Patin } \\
\text { (Panqasionodon }\end{array}$ & 66 & & & & & & & 20 & & 23 \\
\hline & hypopthaimus) & 66 & 1,3 & 12,6 & & & & & 20 & & 2,3 \\
\hline 5. & $\begin{array}{l}\text { Kepiet } \\
\text { (Thynnichthys thynnoides) }\end{array}$ & 41,6 & 0,2 & 7,3 & & 23,3 & & & 27,4 & 0,2 & 2,65 \\
\hline & $\begin{array}{l}\text { Bandeng } \\
\text { (Chanos chanos) }\end{array}$ & & & 25 & 75 & & & & & & 2,75 \\
\hline 7. & $\begin{array}{l}\text { Sepat } \\
\text { (Trichogaster pectoralis) }\end{array}$ & 10 & & & & 90 & & & & & 2,9 \\
\hline 8. & $\begin{array}{l}\text { Oscar } \\
\text { (Amphilophus citrinellus) }\end{array}$ & 5,7 & 28,4 & 1,2 & 0,2 & 25,5 & 0,2 & 0,1 & 20,8 & 18 & 2,93 \\
\hline & $\begin{array}{l}\text { Kebogerang } \\
\text { (Mystus negriceps) }\end{array}$ & 1 & 17 & & 2 & 16,2 & & 37,5 & 18,6 & 7,8 & 2,99 \\
\hline & $\begin{array}{l}\text { Hampal } \\
\text { (Hampala macrolepidota) }\end{array}$ & 11,6 & 2,8 & & & 16 & & & 5,7 & 63,9 & 3,52 \\
\hline & $\begin{array}{l}\text { Kongo } \\
\text { (Parachromis managuensis) }\end{array}$ & & 0,8 & & & & 0,4 & & 3,9 & 94,9 & 3,96 \\
\hline & $\begin{array}{l}\text { Goldsom } \\
\text { (Amphilophus alfari) }\end{array}$ & & & & & & & & & 100 & 4 \\
\hline & $\begin{array}{l}\text { Tagih } \\
\text { (Mystus nemurus) }\end{array}$ & & & & & & & & & 100 & 4 \\
\hline
\end{tabular}

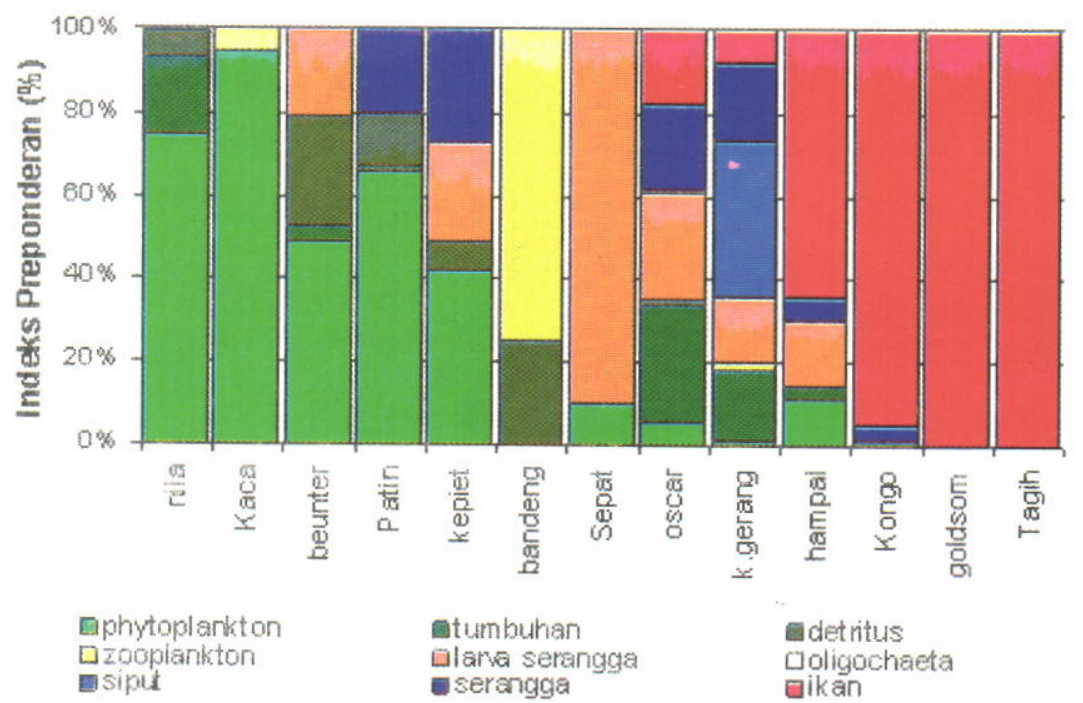

Gambar 2. Komposisi kelompok makanan pada beberapa jenis ikan di Waduk Ir. H. Djuanda.

Figure 2. Food composition of some fishes in ir. H. Djuanda Reservoir.

adalah larva serangga, untuk ikan patin adalah serangga, dan untuk ikan nila adalah tumbuhan dan ikan. Kebiasaan makan ikan beunter tersebut mirip dengan kebiasaan ikan tersebut di Waduk Darma (Tjahjo et al., 2001) dan Waduk Bening (Tjahjo, 1987).
Sedangkan kebiasaan makan ikan nila tersebut berbeda dengan kebiasaan ikan tersebut di Waduk Bening (Tjahjo, 1987), di Waduk Ir. H. Djuanda pada tahun 1988-1989 (Tjahjo, 1991) dan tahun 1993 (Tjahjo, 1994). 
Kelompok ikan yang bersifat omnivora dan cenderung karnivora adalah ikan kebogerang dan bandeng (nilai tingkat trofiknya berkisar 2,50-2,75). Makanan utama ikan kebogerang adalah moluska dan tumbuhan dengan makanan pelengkapnya larva serangga, serangga, dan ikan. Hasil analisis kebiasaan makan kebogerang tersebut mirip dengan kebiasaan ikan tersebut pada tahun 1988-1989 di perairan waduk yang sama (Tjahjo, 1991) dan tahun 1993 (Tjahjo, 1994). Makanan utama ikan bandeng adalah detritus dan zooplankton. Hasil kebiasaan makan ikan bandeng tersebut berbeda dengan hasil pengamatan Kartamihardja (2007) di perairan waduk yang sama pada tahun 2003-2004. Perbedaan tersebut diduga disebabkan perbedaan perubahan komposisi makanan yang tersedia.

Kelompok ikan bersifat karnivora (nilai tingkat trofiknya lebih besar 2,75 ) adalah ikan oscar, hampal, kepiat, dan goldsom. Kebiasaan makan juvenil hampal tersebut mirip dengan kebiasaan makan ikan tersebut di perairan yang sama pada tahun 1984 (Tjahjo, 1988; Tjahjo \& Hardjamulia, 1983) tahun 1998-1989 (Tjahjo, 1990) dan tahun 1993 (Tjahjo, 1994 dan 1994a). Sedangkan untuk ikan oscar relatif berbeda dengan hasil pengamatan Kartamihardja (2007) di perairan waduk yang sama pada tahun 2003-2004. Perbedaan kebiasaan makan ikan oscar tersebut kemungkinan disebabkan perbedaan kelimpahan makanan yang tersedia.

Sejumlah spesies yang hidup bersama dalam suatu komunitas yang seimbang tergantung pada beberapa faktor, antara lain jumlah total macam-macam sumber daya yang dimanfaatkan oleh sekelompok organisme (luas relung), toleransi kesamaan antar kelompok organisme dalam memanfaatkan sumber daya yang tersedia, dan jumlah total sumber daya yang dimanfaatkan oleh komunitas organisme tersebut (MacArthur dalam Hespenheide, 1975).

Analisis luas relung makanan komunitas ikan yang ada di Waduk Ir. H. Djuanda secara kualitatif menunjukkan bahwa jenis ikan yang ada dapat dikelompokkan menjadi tiga kelompok besar (Gambar 3). Kelompok I merupakan kelompok ikan yang mempunyai tingkat trofik berkisar 2-2,5 dan bersifat spesialis dalam memanfaatkan sumber daya makanan, serta berperan sebagai ikan herbivora. Kelompok ini terdiri atas ikan kaca, patin, nila, dan benteur. Kelompok II merupakan kelompok jenis ikan yang mempunyai tingkat trofik berkisar antara 2,5-3,0 dan bersifat generalis dalam memanfaatkan sumber daya makanan yang tersedia, serta berperan sebagai ikan omnivora. Kelompok ini terdiri atas ikan bandeng, kepiat, sepat, kebogerang, dan oscar. Dari lima jenis ikan yang ada dalam kelompok II, hanya ikan oscar yang merupakan jenis ikan yang paling generalis, sehingga jenis ikan ini mempunyai kemampuan yang paling tinggi dalam menyesuaikan fluktuasi kesediaan makanan yang ada. Kelompok III merupakan kelompok ikan yang mempunyai tingkat trofik yang lebih besar dari 3,5 dan bersifat spesialis, serta berperan sebagai ikan predator. Hasil analisis luas relung relatif ini berbeda dengan luas relung ikan tersebut di Waduk Bening (Tjahjo, 1986) dan di Waduk Saguling (Tjahjo, 1987a).

Berdasarkan pada analisis luas relung terhadap distribusi horisontalnya (ruang), komunitas ikan yang ada di Waduk Ir. H. Djuanda dapat dikelompokkan menjadi tiga kelompok besar (Gambar 4). Kelompok I merupakan jenis ikan mempunyai frekuensi kejadian yang rendah, berarti bahwa peluang tertangkapnya jenis ikan tersebut dipengaruhi oleh musim. Walaupun ikan dalam kelompok I (ikan kebogerang, tawes, dan goldsom) mempunyai luas relung yang luas, atau mempunyai distribusi secara horisontal luas. Kelompok I ini terdiri atas hampir seluruh jenis ikan di Waduk Ir. H. Djuanda kecuali ikan nila (masuk kelompok II) dan oscar (masuk kelompok III). Sedangkan ikan oscar yang masuk dalam kelompok III mempunyai distribusi secara ruang dan waktu sangat luas, hal tersebut berarti jenis ikan ini mampu memanfaatkan hampir seluruh perairan dan tidak terpengaruh oleh perubahan musim. Sehingga ditinjau dari distribusi terhadap ruang dan waktu, jenis ikan ini mempunyai peluang berkembang sangat besar di Waduk Ir. H. Djuanda.

Interaksi antar jenis ikan terjadi jika suatu jenis ikan mempunyai pieferensi terhadap makanan dan atau habitat yang sama dengan jenis ikan lainnya. Jika jenis ikan tersebut mempunyai preferensi habitat dan makanan yang sama dengan jenis ikan lainnya, maka ikan tersebut mempunyai peluang kompetisi yang tinggi. Tetapi jika hanya mempunyai kesamaan dalam memanfaatkan makanan atau habitat, maka bersifat komplementaritas.

Berdasaikan pada hubungan antara luas relung makanan dan ruang menunjukkan bahwa ikan oscar dan kebogerang mempunyai potensi keberadaan dan berkembangnya yang baik di Waduk Ir. H. Djuanda: Hal tersebut disebabkan ikan oscar dan kebogerang mampu memanfaatkan sumber daya yang yang ada secara optimal, sehingga ikan ini mampu menyesuaikan fluktuasi kesediaan makanan maupun ruang di perairan tersebut. Ikan nila dan goldsom mempunyai kemampuan cukup baik dalam 


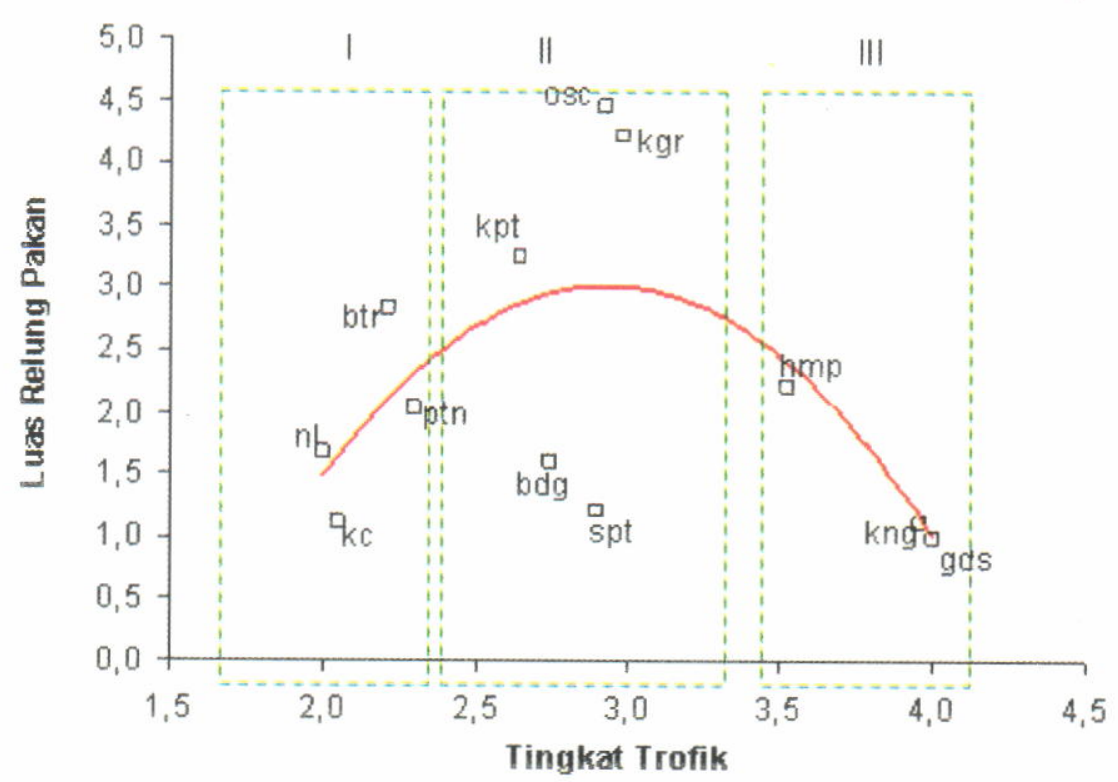

Gambar 3. Hubungan antara tingkat trofik dan luas relung makanan untuk beberapa jenis ikan dominan $(\mathrm{kc}=\mathrm{kaca} ; \mathrm{pt}=$ patin; $\mathrm{nl}=$ nila; $\mathrm{bt}=$ benteur; $\mathrm{bd}=$ bandeng; $\mathrm{kg}=$ kebogerang; ok = oscar; $\mathrm{kp}=$ kepiat; gs = goldsom; I-III = kelompok peran).

Figure 3. Relationship between trophic levels and niche breadth of food for some fishes ( $k c=k a c a ; p t$ $=$ patin; $n \mathrm{l}=$ nila; $b t=$ benteur; $b d=$ bandeng; $k g=$ kebogerang; ok = oscar; $k p=$ kepiat; $g s$ = goldsom; I-III = groups of role) .

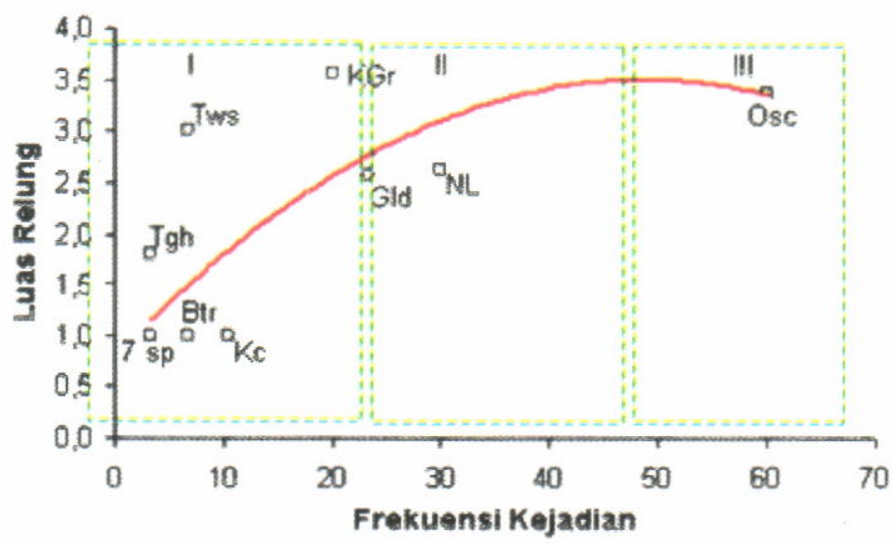

Gambar 4. Hubungan antara frekuensi kejadian dan luas relung ruang untuk beberapa jenis ikan dominan $(\mathrm{Kc}=$ kaca; $\mathrm{Tgh}=$ tagih; NL = nila; $\mathrm{Btr}=$ benteur; Tws = tawes; $\mathrm{KGr}=$ kebogerang; Osc = oscar; Gld = goldsom; $7 \mathrm{sp}=$ patin, sepat, lalawak, nilem, hampal, kepiet, dan kongo; I-III = kelompok ikan),

Figure 4. Relationship between the occurence frequencies and niche breadth of space for fish species $(K c=k a c a ; p t=$ patin; $n l=$ nila; $b t=$ benteur; $b d=$ bandeng; $k g=$ kebogerang; ok = oscar; $k p=$ kepiat; $g s=$ goldsom; I-III = groups fishes $)$.

memanfaatkan ruang perairan ini, tetapi ikan ini bersifat spesialis dalam memanfaatkan makanan yang tersedia, sehingga keberadaan dan perkembangan ikan ini lebih dikendalikan oleh kesediaan kelompok makanan. Sebaliknya, ikan kepiat dan beunter mampu memanfaatkan keanekaragaman kelompok makanan yang ada, tetapi jenis ikan ini mempunyai distribusi yang sangat terbatas, sehingga jenis ikan ini keberadaan dan perkembangan ikan ini lebih dikendalikan oleh kualitas habitatnya. Hal tersebut berarti, ikaan kepiat dan beunter rentan terhadap kerusakan habitat dan polusi.

Hasil secara umum kesamaan dalam memanfaatkan kelimpahan jenis makanan yang tersedia untuk komunitas ikan relatif rendah (Gambar 5), kecuali antara ikan tagih dengan goldsom yang sama-sama mengkonsumsi ikan. Hal ini berarti bahwa 
peluang terjadinya kompetisi antar jenis ikan dalam komunitas ikan di Waduk Ir. H. Djuanda pada tingkat yang relatif rendah. Hasil analisis tersebut realtif sama dengan analisis yang sama di Waduk Saguling (Tjahjo, 1987b) dan di Waduk Ir. H. Djuanda pada tahun 1993 (Tjahjo, 1994).

Berdasarkan pada kesamaan dalam pemanfaatan sumber daya makanan, jenis ikan di Waduk Ir. H. Djuanda dapat dikelompokkan menjadi lima (Gambar 6). Kelompok I merupakan ikan karnivora, kelompok II mewakili ikan herbivora, kelompok II dan IV masingmasing mewakili ikan bersifat mikro karnivora (pemakan larva serangga dan zooplankton), dan kelompok $\mathrm{V}$ merupakan ikan bersifat predator (pemakan ikan). Evaluasi tersebut memperlihatkan bahwa kelompok $\mathrm{V}$ mempunyai peluang terjadinya kompetisi makanan yang paling tinggi, dan kemudian disusul oleh kelompok II. Hal tersebut disebabkan kelompok ikan predator dan herbivora merupakan kelompok ikan yang bersifat sangat spesialis dalam memanfaatkan sumber daya makanan yang ada. Hasil analisis tersebut adalah relatif berbeda dengan hasil pengamatan Kartamihardja (2007) tentang nilai tumpang-tindih ikan bandeng, nila, oscar, dan kongo di daerah limnetik pada tahun 2003-2004 untuk perairan yang sama. Hal tersebut disebabkan kebiasaan makan ikan dan formula (rumus) yang digunakan berbeda.

Hasil secara umum kesamaan dalam rata-rata distribusi jenis ikan secara horisontal menunjukkan bahwa jenis ikan di Waduk Ir. H. Djuanda dapat dipisahkan menjadi tiga kelompok (Gambar 7), yaitu kelompok I merupakan jenis ikan yang mempunyai penyebaran yang sangat luas (ikan oscar). Ikan oscar menyebar hampir merata di keenam stasiun pengamatan. Kelompok II yang mewakili jenis ikan yang mempunyai sebaran yang cukup luas (ikan nila, goldsom, dan kebogerang). Kelompok ikan ini sangat dominan di daerah hulu waduk (Sodong dan Ubrug) dan daerah kantong jaring apung. Hal tersebut mungkin disebabkan ikan nila dan kebogerang tersebut bersifat litoral, sedangkan ikan goldsom lebih banyak di daerah kantong jaring apung (Gambar 8) karena di daerah tersebut tempat berkumpulnya ikan mangsanya. Kelompok III merupakan kelompok jenis ikan yang mempunyai penyebaran sangat terbatas, di mana secara umum banyak ditemukan di satu daerah stasiun pengamatan.

Berdasarkan pada analisis kebiasaan makan, luas relung, dan interaksi antar jenis ikan menunjukkan bahwa peran ekologis masing-masing jenis ikan di Waduk Ir. H. Djuanda sudah cukup Iengkap. Sedangkan berdasarkan pada analisis pemanfaatan ruang secara horisontal di perairan ini menunjukkan bahwa daerah dam atau genangan utama belum sepenuhnya dimanfaatkan secara optimal. Hal tersebut berarti bahwa penebaran jenis ikan dalam rangka mengisi relung ekologi yang kosong tidak diperlukan, tetapi penebaran ikan tersebut diperlukan dalam rangka meningkatkan efektivitas dan efisiensi masing-masing peran dalam memanfaatkan sumber daya yang tersedia khususnya dalam pemanfaatan ruang. Oleh karena itu, dalam upaya untuk efektifvitas dan efisiensi pemanfaatan sumber daya yang tersedia, khususnya di daerah genangan utama, perlu dilakukan penebaran jenis ikan yang bersifat pelagis dan pemakan plankton. Jenis ikan yang dimaksud adalah ikan patin dan bandeng.

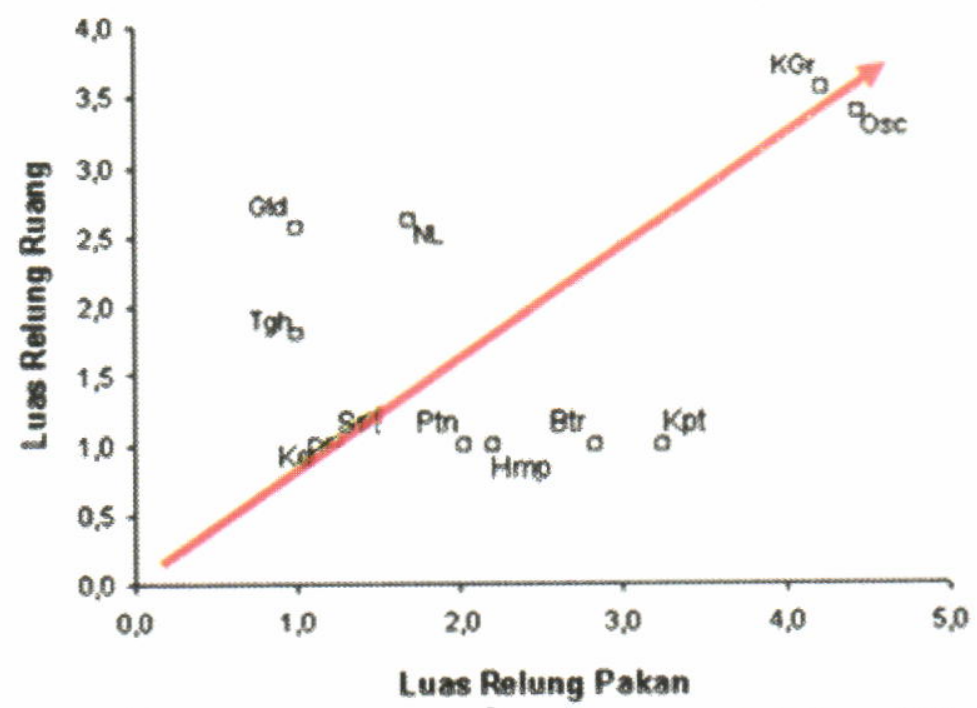

Gambar 5. Hubungan luas relung makanan dan ruang dari beberapa jenis ikan di Waduk Ir. H. Djuanda. Figure 5. Relationship between food and space niche breadth of some fishes in Ir. H. Djuanda Reservoir. 


$$
\begin{aligned}
& \text { I } \\
& \text { II } \\
& \text { III } \\
& \text { V } \mid
\end{aligned}
$$

Gambar 6.

\section{Figure 6.}

\section{Gambar 7.}

Figure 7.

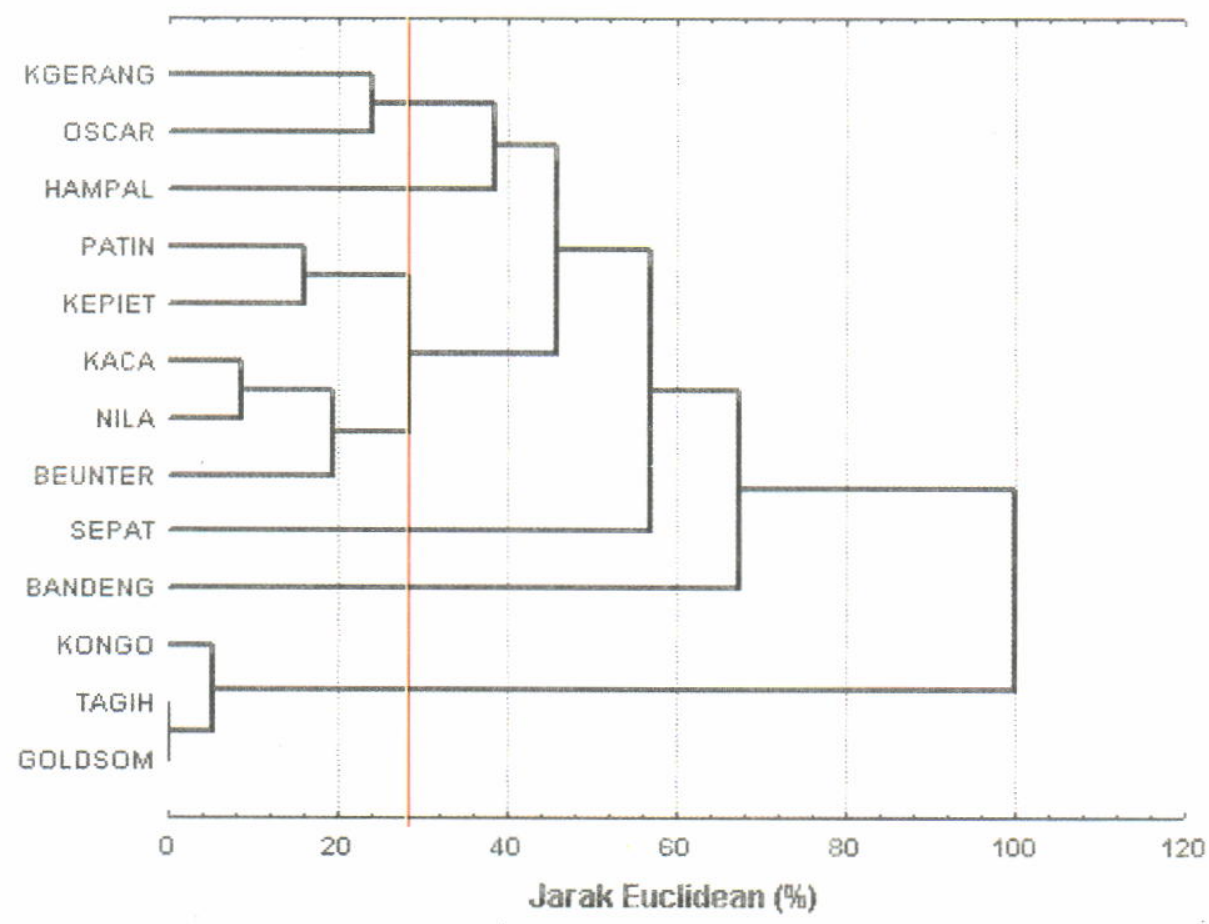

Pengelompokan ikan dalam komunitas ikan berdasarkan pada makanannya di Waduk Ir. $\mathrm{H}$. Djuanda.

Clustering of fish in fish community based on its food habit in Ir. H. Djuanda Reservoir.

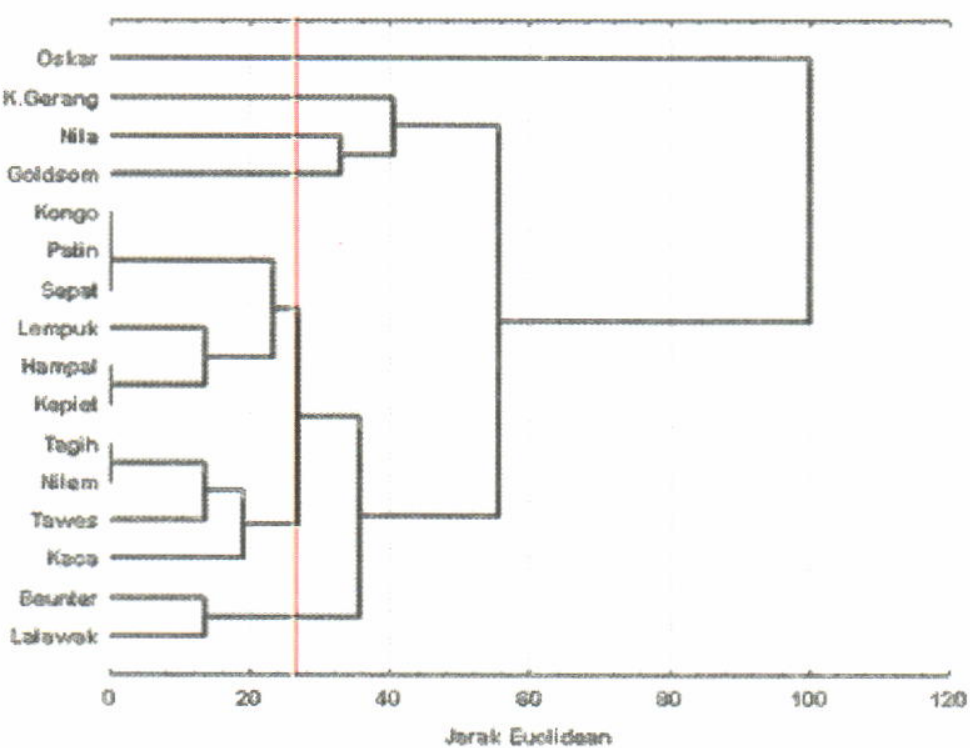

Pengelompokan ikan dalam komunitas ikan berdasarkan pada distribusi horisontalnya di Waduk Ir. H. Djuanda.

Clustering of fish in fish community based on its horizontal distribution in Ir. H. Djuanda Reservoir. 


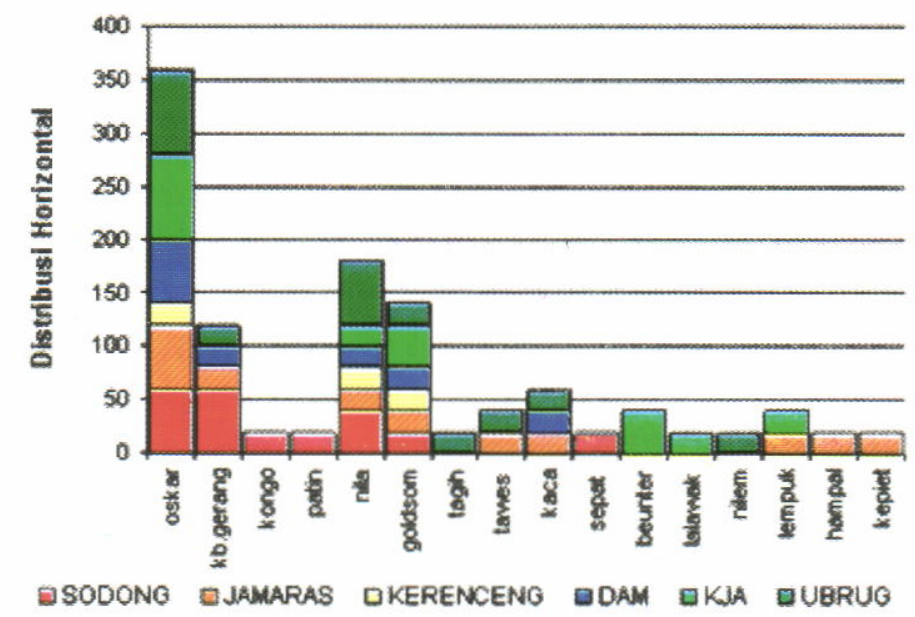

Gambar 8. Distribusi horisotal ikan di Waduk Ir. H. Djuanda.

Figure 8. Horizontally distribution of fish in Ir. H. Djuanda Reservoir.

\section{KESIMPULAN}

Hasil evaluasi peran jenis ikan di Waduk Ir. $\mathrm{H}$. Djuanda dapat disimpulkan bahwa peran dalam pemanfaatan potensi sumber daya makanan yang tersedia di perairan tersebut sudah cukup lengkap, dan dalam pemanfaatan ruang secara horisontal kurang optimal. Sehingga penebaran jenis ikan hanya diperlukan dalam rangka meningkatkan efektivitas dan efisiensi pemanfaatkan sumber daya yang tersedia. Oleh karena itu, dalam upaya untuk efektivitas dan efisiensi pemanfaatan sumber daya yang tersedia, khususnya di daerah genangan utama, perlu dilakukan penebaran jenis ikan yang bersifat pelagis dan pemakan plankton.

\section{PERSANTUNAN}

Tulisan ini merupakan kontribusi dari kegiatan riset monitoring biolimnologi Waduk Ir. H. Djuanda, Jawa Barat, T. A. 2006, di Loka Riset Pemacuan Stok Ikan, Jatiluhur-Purwakarta. Kami mengucapkan terima kasih kepada Kepala Loka Riset Pemacuan Stok Ikan yang telah memberi kesempatan kepada kami untuk melaksanakan kegiatan tersebut.

\section{DAFTAR PUSTAKA}

Caddy, J. F. \& G. D. Sharp. 1986. An ecological framework for marine fishery investigations. FAO Fish. Tech. Pap. 283. 152 pp.

Hespenheide, H. A. 1975. Prey characteristics and predator niche width. In Artemend and Diamon (Eds.). Ecology and Evolution of Communities. The Belknap Press of Harvard University Press. 183193.
Kartamihardja, E. S. 2007. Spektra ukuran biomassa plankton dan potensi pemanfaatannya bagi komunitas ikan di zona limnetik Waduk Ir. $\mathrm{H}$. Djuanda, Jawa Barat. Disertasi. Sekolah Pascasarjana. Institut Pertanian Bogor. Bogor. 137 pp.

Krismono, A. Krismono, \& A. Hardjamulia. 1983. Penelitian populasi ikan di Waduk Jatiluhur, Jawa Barat. Bulletin Penelitian Perikanan Darat. 4 (2): 50-53.

Legendre, L. \& P. Legendre 1983. Numerical Ecology. Elsevier Scientigic Publ. Co. New York.

Ludwig, J. A. \& J. F. Reynolds. 1988. Statistical Ecology: A Primer on Methods and Computing. John Wiley \& Sons. New York. 335 pp.

Nielsen, L. A. \& D. L. Johnson. 1985. Fisheries Techniques. American Fisheries Society. Bethesda. Maryland. 468 pp.

Purnamaningtyas, S. E. 1994. Pengaruh pembendungan Sungai Citarum terhadap struktur komunitas ikan di Waduk Jatiluhur, Jawa Barat. Suplemen. Bulletin Penelitian Perikanan Darat. 12 (2): 41-53.

Sokal, R. R. \& F. J. Rohlf. 1995. Biometry: the Principles Practice of Statistics in Biological Research. W. H. Freeman and Company. 877 pp.

Tjahjo, D. W. H. \& A. Hardjamulia. 1983. Periode makan dan aktivitas ikan hampal (Hampala macrolepidota) di Waduk Jatiluhur, Jawa Barat. Bulletin Penelitian Perikanan Darat. 4 (2): 54-58. 
Tjahjo, D. W. H. 1986. Luas relung dan kompetisi makanan komunitas ikan di Waduk Bening, Jawa Timur. Bulletin Penelitian Perikanan Darat. 69-77.

Tjahjo, D. W. H. 1987. Kebiasaan makanan komunitas ikan di Waduk Bening, Jawa Timur. Bulletin Penenelitian Perikanan Darat. 6 (1): 59-64.

Tjahjo, D. W. H. 1987a. Studi pendahuluan kompetisi makanan komunitas ikan di Waduk Saguling. Bulletin Penelitian Perikanan Darat. 6 (1): 78-84.

Tjahjo, D. W. H. 1988. Kebiasaan makanan komunitas ikan di Waduk Saguling, Jawa Barat. Bulletin Penelitian Perikanan Darat. 7 (1): 86-91.

Tjahjo, D. W. H. 1990. Penelitian Optimasi dan Teknik Pengelolaan Perikanan Waduk Jatiluhur. Sub Balai Penelitian Perikanan Air Tawar, Jatiluhur. 28 pp.

Tjahjo, D. W. H. 1991. Kebiasaan makanan komunitas ikan di Waduk Jatiluhur. Bulletin Penelitian Perikanan Darat. $10(2): 1-8$.

Tjahjo, D. W. H. \& C. Umar. 1994. Interaksi beberapa jenis ikan di Waduk Jatiluhur, Jawa Barat. Suplemen. Bulletin Penelitian Perikanan Darat. 12 (2): 67-77.
Tjahjo, D. W. H. 1994. Studi pemanfaatan makanan oleh juvenil hampal (Hampala macrolepidota) di Waduk Jatiluhur, Jawa Barat. Suplemen. Bulletin Penelitian Perikanan Darat. 12 (2): 54-66.

Tjahjo, D. W. H. 1994a. Strategi pemanfaatan makanan juvenil hampal (Hampala macrolepidota) di Waduk Jatiluhur, Jawa Barat. Tesis. Program Pascasarjana. Institut Pertanian Bogor. Bogor. 73 pp.

Tjahjo, D. W. H., S. Nuroniah, \& S. E. Purnamaningtyas. 2001. Evaluasi biolimnologi dan relung ekologi komunitas ikan untuk menentukan jenis ikan yang ditebar di Waduk Darma. Jurnal Penelitian Perikanan Indonesia. 7 (1): 10-24.

Tjahjo, D. W. H. 2004. Kemantapan hasil tangkapan, keterkaitannya dengan sintasan, pertumbuhan, dan intensitas penangkapan udang galah (Macrobrachium rosenbergii) yang ditebarkan di Waduk Darma, Kuningan, Jawa Barat. Disertasi. Sekolah Pascasarjana. Institut Pertanian Bogor. Bogor. $149 \mathrm{pp}$. 


\title{
SEBARAN INTENSITAS CAHAYA PADA BAGAN TANCAP DI PERAIRAN PANTAI KEPULAUAN SERIBU
}

\author{
Erfind Nurdin dan Hufiadi \\ Peneliti pada Balai Riset Perikanan Laut, Muara Baru-Jakarta \\ Teregistrasi I tanggal: 13 Mei 2008; Diterima setelah perbaikan tanggal: 11 September 2008; \\ Disetujui terbit tanggal: 13 April 2009
}

\begin{abstract}
ABSTRAK
Penggunaan intensitas cahaya pada unit penangkapan bagan cenderung meningkat dari waktu ke'waktu. Hal ini didasari pada persepsi nelayan bahwa intensitas cahaya yang tinggi akan meningkatkan hasil tangkapan. Penelitian dilaksanakan di perairan Pulau Lancang (Kepulauan Seribu) pada bulan Mei 2005 dengan tujuan untuk mengetahui rentang intensitas cahaya serta tingkah laku ikan di bawah pengaruh cahaya. Penelitian dilakukan melalui pengamatan dan pengukuran nilai intensitas cahaya dengan meggunakan quantum meter LI COR $250\left(\mu \mathrm{mol} \mathrm{s}^{-1} \mathrm{~m}^{-2}\right)$ pada jenis lampu yang berbeda, dan digunakan pula echosounder Simrad EY 500 untuk memperoleh data sebaran kelompok ikan. Keberadaan ikan lebih banyak ditemukan pada lahan transisi perbatasan antara light zone dan dark zone dengan nilai intensitas kurang dari $0,01 \mu \mathrm{mol} \mathrm{s} \mathrm{s}^{-1} \mathrm{~m}^{-2}$. Nilai panjang ikan (FL) tangkapan didominansi oleh ukuran kecil $(-70-50 \mathrm{db})$, dengan modus tertinggi pada nilai FL (fork Length) lebih kecil dari nilai Lm (length at maturity). Hasil ini menandakan bahwa ukuran ikan tersebut belum layak tangkap.
\end{abstract}

KATA KUNCl: bagan tancap, intensitas cahaya, lampu mercuri, petromak

ABSTRACT: Distribution of light intensity on fixed bamboo liftnet in coastal waters of Seribu Island. By: Erfind Nurdin and Hufiadi

The use of light intensity on fixed bamboo lift net (bagan) tends to increase by time. Fishermen believe that the intensity always increases linearly with the catch. This research was conducted on May 2005 in Lancang Island (Seribu Islands). The aim of this study are to know the range of light intensity used and the behaviour of fish under the light influence. LI COR 250 Quantum meter $\left(\mu \mathrm{mol} \mathrm{s}^{-1} \mathrm{~m}^{-2}\right)$ for light intensity at different lamps amount and Simrad EY 500 scientific echosounder was utilized to obtain the data of fish school around fixed. The fish school was found in high quantity at the transition area between light and dark zones with intensity value at less than $0.01 \mu \mathrm{mol} \mathrm{s} \mathrm{s}^{-1} \mathrm{~m}^{2}$. The fork length of captured fish was dominated by small fish (-70--50 db), with the highest modus fork length smaller than the length at maturity. This means that the size of fish is not feasible to be caught.

\section{KEYWORDS: fixed bamboo liftnet, light intensity, mercury lamp, kerosene pressure lamp}

\section{PENDAHULUAN}

Metode penangkapan ikan yang menggunakan alat bantu cahaya di dalam pengoperasiannya diistilahkan sebagai perikanan cahaya (light fishing). Alat tangkap ini merupakan salah satu teknologi penangkapan yang dianggap sukses dan mengalami perkembangan yang pesat (Arimoto, 1999). Berdasarkan pada cara pengoperasiannya, bagan dimasukan ke dalam kelompok alat tangkap lift net (jaring angkat), tetapi karena menggunakan lampu sebagai alat untuk menarik perhatian ikan, maka dapat juga dikelompokan ke dalam light fishing (Subani \& Barus, 1989). Menurut Ayodhyoa (1981), peristiwa berkumpulnya ikan di bawah sumber cahaya disebabkan karena adanya sifat fototaksis positif dan makanan.
Bagan merupakan salah satu jenis alat tangkap yang telah lama dikenal masyarakat Indonesia. Dalam perkembangannya bagan dibedakan menjadi 2 jenis yaitu bagan tancap (fixed lift net) yang beroperasi pada kedalaman 5-10 m dan bagan apung atau bagan perahu (floated lift net) yang dapat berpindah (Baskoro, 1999). Sumber cahaya yang digunakan pada perikanan bagan bervariasi mulai dari lampu petromak, lampu dop, serta lampu fluorocent dengan daya 250-puluhan ribuan watt seperti pada kasus bagan rambo di perairan Sulawesi Selatan (Sudirman, 2003).

Tipe alat tangkap yang menggunakan alat bantu cahaya pada umumnya dioperasikan untuk menangkap jenis ikan yang termasuk kelompok ikan pelagis. Terkait dengan penggunaan alat bantu 
cahaya, adalah suatu kenyataan bahwa pada tataran praktisi lapangan (pengusaha dan nelayan) terdapat kecenderungan adanya penggunaan intensitas cahaya yang semakin besar dalam operasi penangkapan berbagai jenis alat tangkap. Kebanyakan orang beranggapan bahwa semakin besar intensitas cahaya lampu yang dipakai, maka akan semakin banyak hasil tangkapan ikan yang diperoleh.

Kegiatan (preliminary research) ini bertujuan untuk memperoleh informasi dasar kegiatan penangkapan yang menggunakan bagan tancap dengan jenis sumber cahaya yang berbeda dengan tekanan pada:

1. Pengukuran sebaran cahaya secara vertikal dan horisontal.

2. Pengamatan pola pengelompokan ikan di bawah pengaruh cahaya lampu.

3. Komposisi hasil tangkapan (jenis dan ukuran spesies dominan).

\section{BAHAN DAN METODE}

Penelitian dilakukan pada tanggal 13-19 Mei 2005 di Pulau Lancang (Kepulauan Seribu) pada posisi $5^{\circ} 56^{\prime} 26^{\prime \prime} \mathrm{S}$ atau $106^{\circ} 35^{\prime} 20^{\prime \prime} \mathrm{E}$. Pengamatan dilakukan 2 kali ulangan untuk tiap jenis lampu mercury 1.000 watt (1 unit) dan petromak (10 unit) dengan lama penyinaran 10 jam.

Pengamatan lampu mercury 1.000 watt dan petromak 10 unit dilakukan karena banyak nelayan yang menggunakannya dengan anggapan semakin besar daya dan banyaknya jumiah lampu yang dipakai, maka hasil tangkapan akan semakin bertambah.

\section{Alat dan Bahan}

1. Bagan bambu ukuran panjang $12 \mathrm{~m}$, lebar $12 \mathrm{~m}$, dan tinggi $21 \mathrm{~m}$.

2. Perahu kayu panjang $12 \mathrm{~m}$, lebar $2,6 \mathrm{~m}$, dan dalam $1 \mathrm{~m}$.

3. Lampu petromak dan mercuri.

4. LI-250 light meter (quantum meter).

5. Simrad EY 500 (akustik).

6. GPS.

7. Alat ukur bobot (timbangan).

8. Alat ukur panjang (meteran)

9. Pelampung bola plastik diameter $12 \mathrm{~cm}$.

10. Alat ukur kuat arus (stopwatch).

11. Sechi disk.

12. Buku identifikasi FAO, (Carpenter \& Niem, 1998).

\section{Pengumpulan Data}

Pengukuran intensitas cahaya yang dilakukan mencakup sebaran mendatar (horisontal) dan vertikal berdasarkan pada kedalaman. Data sebaran intensitas cahaya di kolom perairan diukur dengan menggunakan Photometer LICOR LI-250 dengan satuan $\mu \mathrm{mol} \mathrm{s}{ }^{-1} \mathrm{~m}^{-2}$. Sebaran nilai intensitas cahaya secara horisontal dan vertikal diperoleh dengan mengukur mulai dari pusat atau sumber cahaya dan bergerak menjauhi sumber cahaya pada setiap jarak $1 \mathrm{~m}$ sampai dengan diperoleh nilai cahaya mendekati atau sama dengan nol.

Pengumpulan data sebaran gerombolan ikan dilakukan dengan menggunakan Portable Scientific Echosounder SIMRAD EY 500 dengan tranduser Split Beam Acoustic System yang berfrekuensi $38 \mathrm{kHz}$ dan dilengkapi dengan 1 unit komputer untuk merekam data yang diperoleh dari Echosounder. Data akustik direkam secara terus-menerus dalam hard disk komputer. Data yang diperoleh di lapangan berupa data gram kemudian diubah menjadi data threshold. Perolehan data akustik dilakukan dengan metode pengintegrasian echo secara terus-menerus dengan menggunakan target strength threshold $-70 \mathrm{~dB}$ dan SV threshold -80 dB, dengan interval TS $-3 \mathrm{~dB}$.

Pengamatan sebaran ikan pada alat tangkap bagan dilakukan dengan 2 pendekatan; pertama dilakukan dengan metode tetap (statis) di atas bagan dengan sistem tranduser digantung pada posisi tepat di bawah lampu. Pengamatan ini bertujuan untuk mengetahui pola pengelompokan ikan di bawah cahaya terhadap lamanya periode penyinaran cahaya.

Pengamatan kedua dilakukan secara spiral dengan mengitari perairan di sekitar bagan, ini bertujuan untuk mengetahui seberapa jauh pengaruh cahaya terhadap pengerombolan ikan di sekitar bagan. Pengamatan dilakukan dengan menggunakan perahu, tranduser dipasang pada sisi kiri perahu dengan sistem side mounted. Bentuk trek yang digunakan pada pengamatan ini adalah bentuk spiral, sebagai titik awal untuk perekaman data akustik adalah titik terdekat dengan bagan, kemudian makin menjauhi bagan sampai dengan jarak tertentu di mana intensitas cahaya diperkirakan sudah lemah.

Perekaman data akustik dilakukan berbasis pada posisi geografi (GPS) dan waktu, data jumlah sasaran disimpan secara simultan dengan data waktu dan posisi geografis kapal. Data ini diolah dengan cara ping to ping analysis. 
Pengukuran kuat arus permukaan air laut menggunakan pelampung bola yang diikat pada seutas tali dan stopwatch untuk mencatat lama waktu yang dibutuhkan, sedangkan kecerahan diukur dengan sechi disk. Pengukuran terhadap panjang bobot ikan hasil tangkapan dilakukan menggunakan timbangan dan measuring paper. Identifikasi jenis ikan hasil tangkapan menggunakan buku FAO Species Identification Guide for Fishery Purposes (Carpenter \& Niem, 1998).

\section{Analisis Data}

Analisis intensitas cahaya dari hasil pengukuran besaran nilai yang tercatat pada photometerdilakukan secara deskriptif dengan tampilan grafik yang dianalisis menggunakan software MS-Excel. Sedangkan analisis akustik menggunakan software SHOW, di mana setiap titik contoh data akan menghasilkan satu unit data sasaran. Data sasaran tunggal diintegrasikan untuk mendapatkan nilai densitas dan besaran ikan dugaan berdasarkan pada nilai target strength dari sasaran. Integrasi echo dilakukan berdasarkan pada teori echo integratoryang sudah baku yang terdapat pada software EP 500. Data hasil keluaran dari software SHOW dan EP 500 berupa data dalam format ASCII. Data keluaran ini selanjutnya diolah dengan menggunakan program sederhana yang dibuat dengan fasilitas yang tersedia dalam bahasa pemrograman BASIC dan ditabulasi dengan spreadsheet excel. Analisis lanjutan dilakukan secara deskriptif dengan tampilan grafik dengan menggunakan software MS-Exceldan surfer.

\section{HASIL DAN BAHASAN}

\section{Pengukuran Intensitas Cahaya}

Hasil pengukuran di lapangan menunjukkan bahwa kuat arus di sekitar bagan rata-rata mencapai $3,45 \mathrm{~m}$ per menit dengan arah arus yang berlainan setiap harinya dan kecerahan di sekitar bagan rata-rata mencapai $3,7 \mathrm{~m}$.

Sebaran cahaya dalam kolom air dengan lampu mercury 1.000 watt dan 10 unit petromak secara umum memiliki pola yang hampir sama (Gambar 1 dan 2 ). Intensitas cahaya lampu mercury 1.000 watt secara horisontal pada permukaan perairan mencapai $0,004 \mu \mathrm{mol} \mathrm{s}^{-1} \mathrm{~m}^{-2}$ pada jarak $10 \mathrm{~m}$ dari pusat cahaya dan secara vertikal pada pusat cahaya intensitas mencapai $0,002 \mu \mathrm{mol} \mathrm{s}^{-1} \mathrm{~m}^{-2}$ pada kedalaman $10 \mathrm{~m}$. Intensitas cahaya petromak 10 lampu secara horisontal pada permukaan perairan mencapai 0,014 $\mu \mathrm{mol} \mathrm{s} \mathrm{s}^{-1} \mathrm{~m}^{-2}$ pada jarak $6 \mathrm{~m}$ dari pusat cahaya dan secara vertikal pada pusat cahaya intensitas mencapai $0,024 \mu \mathrm{mol} \mathrm{s}^{-1} \mathrm{~m}^{-2}$ pada kedalaman $6 \mathrm{~m}$.

Gambar 1 dan 2 menunjukan bahwa sebaran lampu mercuri dengan daya 1.000 watt terdeteksi adanya intensitas cahaya pada jarak $10 \mathrm{~m}$ dari pusat cahaya $0,004 \mu \mathrm{mol} \mathrm{s}^{-1} \mathrm{~m}^{-2}$ (horisontal) dan $0,002 \mu \mathrm{mol}$ $\mathrm{s}^{-1} \mathrm{~m}^{-2}$ (vertikal), sedangkan pada petromak (10 unit) sebaran intensitas cahaya hanya mencapai jarak 6 $\mathrm{m}$ dari pusat cahaya $0,014 \mu \mathrm{mol} \mathrm{s}^{-1} \mathrm{~m}^{-2}$ (horisontal) dan $0,024 \mu \mathrm{mol} \mathrm{s}^{-1} \mathrm{~m}^{-2}$ (vertikal). Berdasarkan pada data sebaran intensitas cahaya yang diperoleh terlihat bahwa besaran daya lampu mercuri dan jumlah lampu petromak berbanding lurus dengan penetrasinya, yaitu semakin besar daya atau jumlah lampu yang digunakan maka akan semakin luas lahan yang dipengaruhi.

Sebaran cahaya dalam kolom air merupakan proses yang kompleks dan dipengaruhi oleh banyak faktor. Di samping nilai intensitas, kecerahan, jumlah partikel terlarut, arus, serta sudut datang cahaya merupakan beberapa hal yang menentukan jangkauan sebaran cahaya. Berdasarkan pada data sebaran intensitas cahaya yang diperoleh selama penelitian

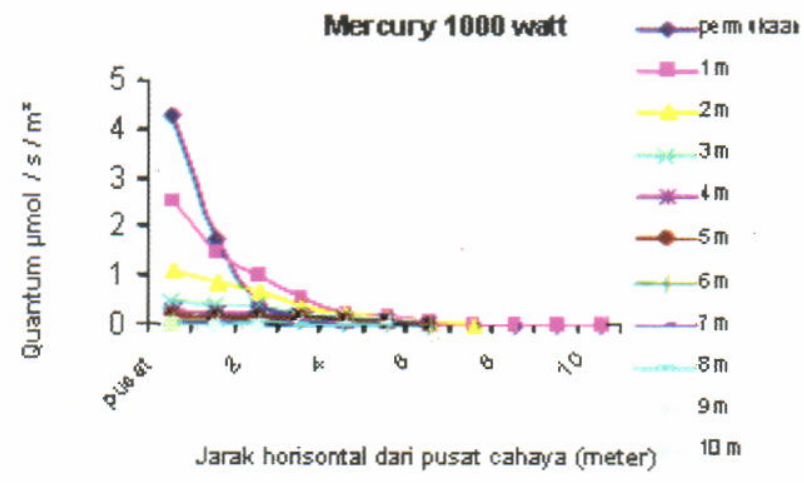

Gambar 1. Sebaran cahaya lampu mercury 1.000 watt.

Figure 1. Light distribution of mercury lamp 1,000 watt. 


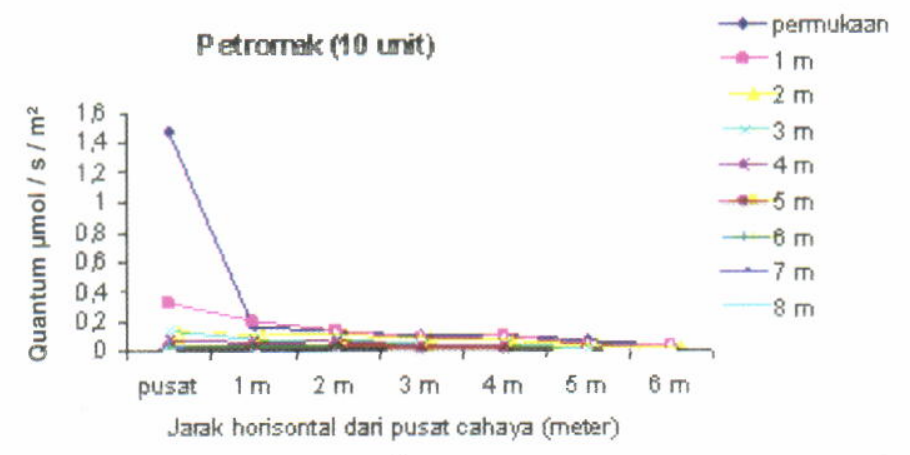

Gambar 2. Sebaran cahaya petromak (10 unit).

Figure 2. Light distribution of kerosene pressured lamp (10 units).

tampak bahwa, besaran daya lampu mercuri dan jumlah lampu petromak berbanding lurus dengan penetrasinya. Semakin besar daya atau jumlah lampu, maka akan semakin luas lahan yang mampu dipengaruhi.

\section{Sebaran Ikan di Sekitar Bagan Tancap}

\section{Stasioner}

\section{10 petromak}

Dari hasil pengukuran didapatkan light zone pada perlakuan ini adalah $8 \mathrm{~m}$. Analisis akustik dilakukan pada strata $8 \mathrm{~m}$ untuk light zone dan 8-16 m untuk mendapatkan gambaran pengelompokan ikan pada dark zone. Dari hasil plot nilai scattering area sasaran di bawah pengaruh cahaya dapat dilihat bahwa pengaruh 10 unit lampu petromak terhadap pengerombolan ikan pada light zone cenderung menurun seiring lamanya penyinaran, selanjutnya ikan-ikan cenderung semakin terkonsentrasi pada sekitar daerah dark zone (Gambar 3).

Variasi nilai scattering area pada perlakuan ini cenderung berbeda. Ikan-ikan yang terdeteksi terpisah menjadi 2 kelompok yaitu kelompok ikan yang cenderung berada di kolom perairan bagian atas dekat dengan sumber cahaya (A) dan kelompok kedua adalah ikan-ikan yang cenderung memilih berada pada dekat dasar perairan (B). Gambar 4 terlihat bahwa sasaran yang mengelompok pada permukaan perairan (light zone) (A) dan terdapat pula mengelompok di dekat dasar perairan (B). Gerombolan ikan yang terlihat pada echogram hasil deteksi untuk perlakuan ini juga memperlihatkan kumpulan-kumpulan sasaran yang relatif kecil antara $-70--50 \mathrm{db}$. Hal ini dapat dibandingkan dengan pengukuran panjang dan bobot ikan dominan hasil tangkapan (lihat Tabel 2), yang menunjukkan bahwa nilai modus fork length lebih rendah dibanding dengan nilai length of maturity.

\section{Lampu Mercuri 1.000 watt}

Pada lampu mercury 1.000 watt nilai light zone yang didapatkan $10 \mathrm{~m}$ baik secara vertikal maupun horisontal. Hal ini berpengaruh terhadap pengelompokan ikan di bawah penyinaran lampu mercury 1.000 watt. Analisis akustik untuk light zone dilakukan pada strata $10 \mathrm{~m}$ dan 10-16 m untuk dark zone.

Variasi nilai scattering area pada light zone juga memiliki kecenderungan meningkat seiring lamanya penyinaran lampu, begitu pula pola yang terdapat pada dark zone, peningkatan secara gradual terlihat pada dark zone (Gambar 5). Gerombolan ikan yang terlihat pada echogram hasil deteksi untuk perlakuan ini juga memperlihatkan kumpulan-kumpulan sasaran yang relatif kecil antara $-70-50 \mathrm{db}$ (Gambar 6).

Perilaku ikan-ikan pada perlakuan lampu mercury 1.000 watt cenderung memiliki pola yang sama dengan lampu petromak 10 unit. Hal ini terjadi diduga karena adanya kelompok ikan dengan spesies yang sama untuk setiap jenis lampu yang digunakan yang disebabkan lokasi penelitian pada habitat yang sama. Semakin lama penyinaran berlangsung, maka konsentrasi gerombolan ikan akan semakin mendekat ke sumber cahaya. Ikan-ikan yang terdeteksi terpisah menjadi 2 kelompok yaitu kelompok ikan yang cenderung berada di kolom perairan bagian atas dekat dengan pusat cahaya (light zone) dan bagian bawah (dark zone) berada pada dekat dasar perairan (Gambar 6). 
Variasi vilai SA target pads light zone

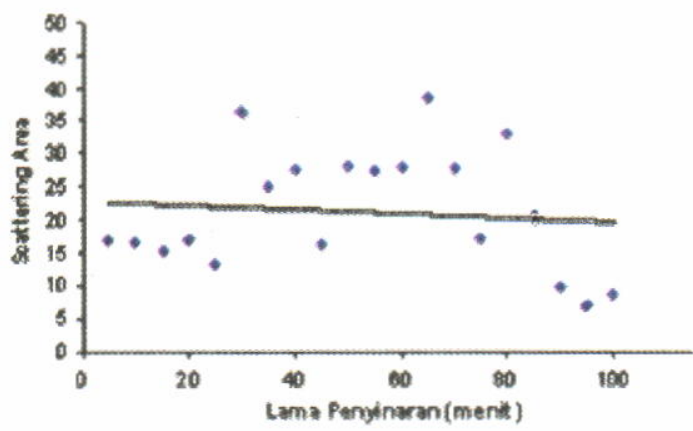

Variasi nilk SA target poch dark zone

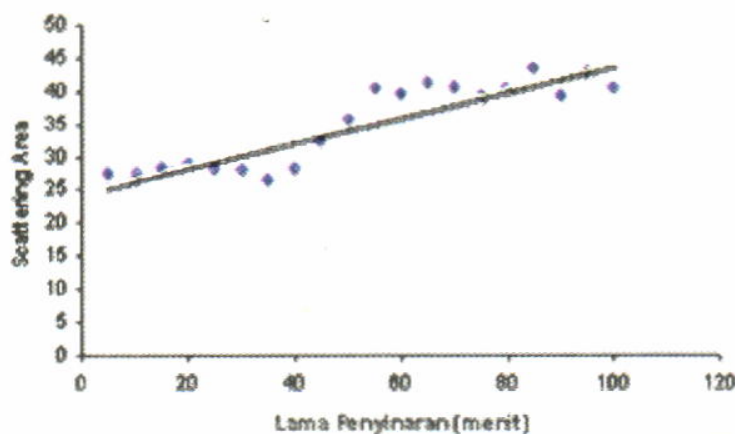

Gambar 3. Variasi nilai scattering area pada lampu petromak (10 unit).

Figure 3. Variation of scattering area value at light distribution of kerosene pressured lamp (10 units).

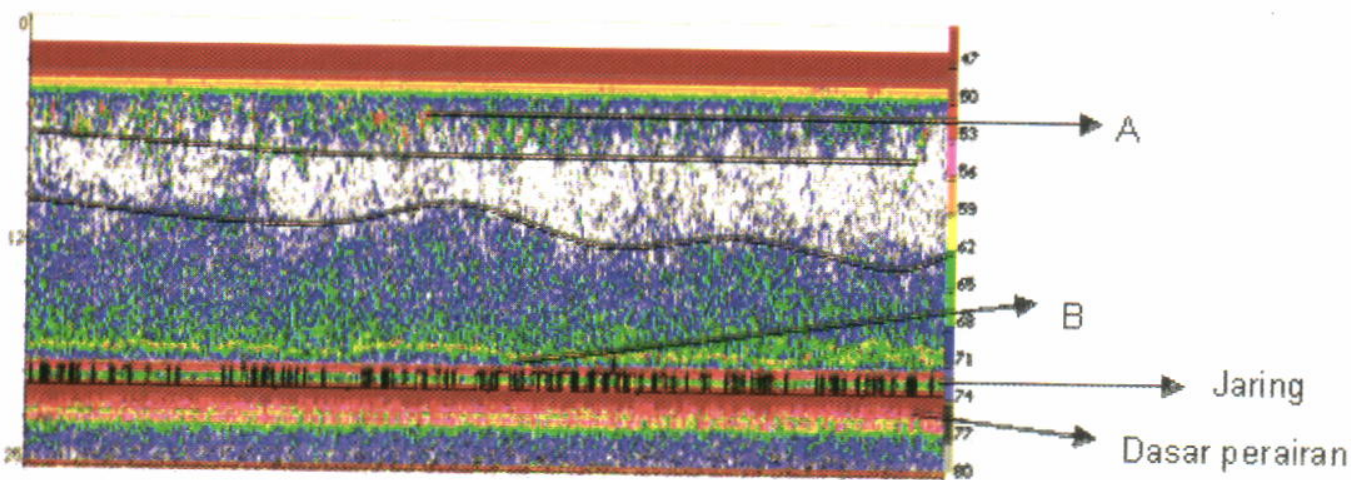

Gambar 4. Echogram lampu 10 unit petromak, (A) kelompok ikan pada daerah terang, (B) kelompok ikan pada daerah gelap.

Figure 4. Echogram of kerosene pressured lamp (10 units), (A) fish scholling in light zone, (B) fish scholling in dark zone.

Variasi nilai sk target pada light zone

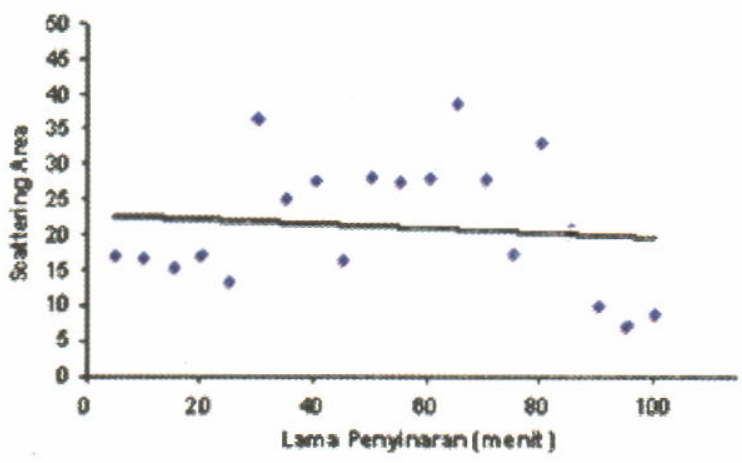

Variasi nibi sa target pach dark zone

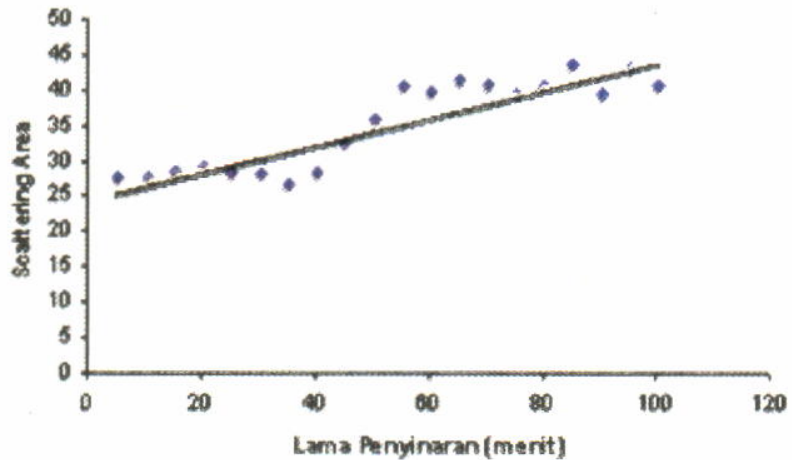

Gambar 5. Variasi nilai scattering area pada perlakuan lampu mercury 1.000 watt.

Figure 5. Variation of scattering area value at light distribution of mercury lamp 1.000 watt. 


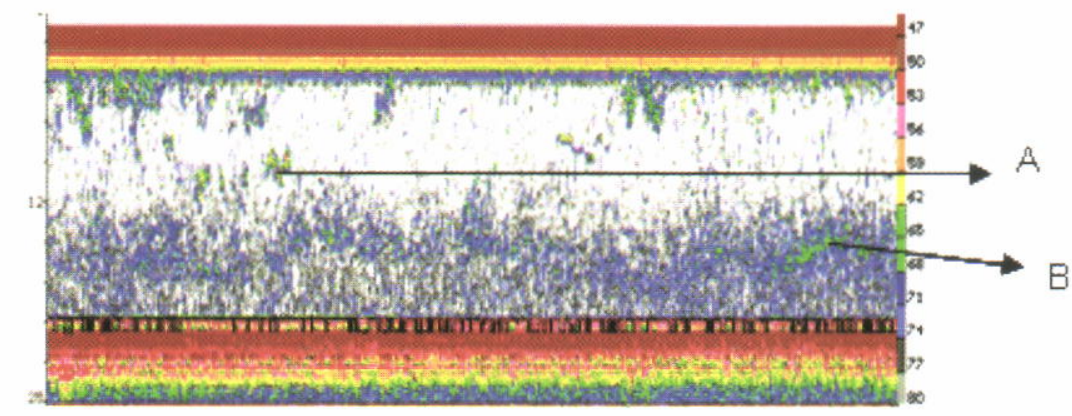

Gambar 6. Echogram lampu mercury 1.000 watt, (A) kelompok ikan pada daerah terang, (B) kelompok ikan pada daerah gelap.

Figure 6. Echogram of mercury lamp 1,000 watt, (A) fish scholling in light zone, (B) fish scholling in dark

\section{Covered(Spiral)}

Luasan cakupan light zone secara horisontal untuk perlakuan 10 petromak adalah daerah dengan jari-jari $6 \mathrm{~m}$, lamanya penyinaran tampak berpengaruh terhadap ikan-ikan yang terdeteksi. Terlihat pada sounding saat waktu penyinaran yang lebih lama lebih banyak sasaran yang terdeteksi dan semakin terkonsentrasi mendekati sumber cahaya. Sasaran terdeteksi sampai dengan jarak $38 \mathrm{~m}$ dari pusat cahaya (Gambar 7).

Luasan cakupan light zone secara horisontal untuk perlakuan lampu mercury 1.000 watt adalah daerah dengan jari-jari $10 \mathrm{~m}$. Terlihat dengan jelas bahwa sasaran-sasaran yang terkonsentarsi di bawah pengaruh cahaya mercurymeningkat dengan cakupan lahan yang lebih luas, sasaran terdeteksi sampai dengan radius $50 \mathrm{~m}$ dari sumber cahaya. Lama penyinaran juga tampak sangat berpengaruh terhadap jumlah sasaran yang terdeteksi di sekitar bagan (Gambar 7).

Menurut Iskandar et al. (2004), peningkatan jumlah ikan yang berkumpul dengan bertambahnya waktu penyinaran diduga terjadi karena adanya mekanisme rantai makanan, di mana ikan-ikan kecil akan merangsang kehadiran predator ke lokasi penangkapan, sehingga meningkatkan jumlah individu di lokasi penangkapan.

Hal ini menunjukkan bahwa semakin lama penyinaran dilakukan, maka kelompok ikan fototaksis positif akan lebih terkonsentrasi pada sumber cahaya, begitu juga plankton dan ikan kecil sebagai makanan yang menimbulkan daya tarik dan perhatian kelompok ikan lain di luar kelompok ikan fototaksis positif yang terkonsentrasi di luar wilayah light zone, sehingga dapat menimbulkan suatu rantai makanan.
Menurut Ayodhyoa (1981), peristiwa berkumpulnya ikan di bawah sumber cahaya disebabkan karena adanya sifat fototaksis positif dan makanan. Atmadja (1994) menjelaskan bahwa ikan berkumpul di sekitar cahaya, karena fototaksis positif serta terkonsentrasinya plankton dan ikan kecil yang menarik perhatian ikan besar sebagai pemangsa. Puspito (2006) mengatakan bahwa keberhasilan penangkapan ikan dengan bagan salah satunya sangat ditentukan oleh intensitas cahaya yang masuk ke dalam kolom perairan, semakin besar intensitas cahaya yang masuk ke dalam kolom perairan, maka diperkirakan semakin besar jumlah ikan yang bersifat fototaksis positif mendatangi bagan.

\section{Hasil Tangkapan}

Hasil tangkapan di lapangan menunjukkan bahwa ikan yang dominan tertangkap adalah jenis ikan pelagis kecil walaupun demikian juga tertangkap beberapa jenis ikan dasar. Untuk lampu mercury 1.000 watt rata-rata hasil tangkapan per setting $22,811 \mathrm{~g}$ dan untuk lampu petromak 10 unit 7,679 g (Tabel 1).

Dari hasil tangkapan yang diperoleh terlihat bahwa komposisi jenis ikan didominansi oleh ikan pelagis kecil $74,55 \%$ dan ikan dasar 25,45\% (Gambar 8 ). Tertangkapnya jenis ikan dasar pada pengoperasian alat tangkap bagan dapat dikarenakan oleh jaring yang digunakan sampai dengan dasar perairan dengan kedalaman $21 \mathrm{~m}$.

Menurut Baskoro et al. (2004), keragaman spesies yang tertangkap saat haulling pada bagan rambo cenderung didominansi oleh jenis ikan pelagis kecil dan moluska, sedangkan ikan demersal bervariasi. $\mathrm{Hal}$ ini dikarenakan ikan-ikan jenis pelagis sudah terbiasa dengan kondisi terang, sedangkan jenis ikan demersal yang tertangkap ditentukan oleh keadaan fishing ground. 

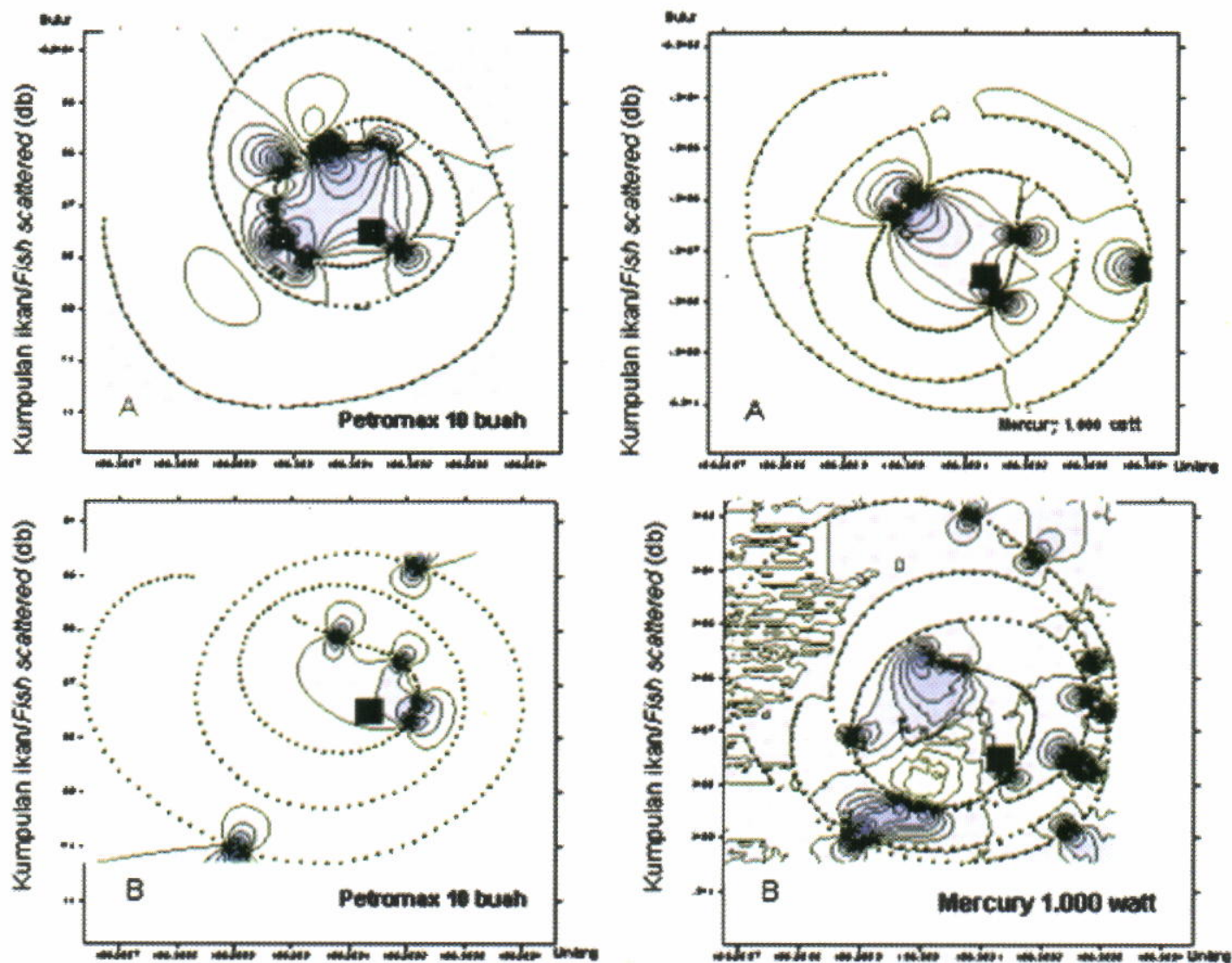

Gambar 7. Hasil pengamatan (A) 4 jam penyinaran dan (B) 8 jam penyinaran.

Figure 7. The observation result ( $A$ ) 4 hours illumination and (B) 8 hours illumination.

Tabel 1. Hasil tangkapan bagan 2 kali ulangan (haulling)

Table 1. Catch of fixed bamboo liftnet in 2 replications (haulling)

\begin{tabular}{lcc}
\hline \multicolumn{1}{c}{ Jenis ikan/Species } & $\begin{array}{c}\text { Mercury Bobot/ } \\
\text { Mercury lamp weight (g) }\end{array}$ & $\begin{array}{c}\text { Petromak Bobot/ } \\
\text { Petromak lamp weight (g) }\end{array}$ \\
\hline Petek (Leiognathus bindus) & $1.2574,0$ & $2.839,7$ \\
Cumi (Loligo sp.) & $1.876,7$ & $2.803,2$ \\
Teri (Stelephorus indicius) & $9.023,0$ & $7.020,0$ \\
Tembang (Sardinella fimbriata) & $7.272,9$ & $1.129,9$ \\
Bentong (Selar crumenophtalmus) & $3.986,4$ & 92,0 \\
Selar kuning (Selaroides leptolepis) & $10.339,2$ & $1.186,6$ \\
Torani (Cypsilurus poecilopterus) & 375,0 & 0,0 \\
Cendro (Tylosurus crocodilus) & 70,0 & 0,0 \\
Kembung (Rastrelliger brachysoma) & 15,0 & 0,0 \\
Baronang (Siganus guttatus) & 90,0 & 16,7 \\
Layur (Trichiurus sp.) & 0,0 & 270,0 \\
Jumlah & $\mathbf{4 5 . 6 2 2 , 2}$ & $\mathbf{1 5 . 3 5 8 , 0}$
\end{tabular}

Jenis hasil tangkapan

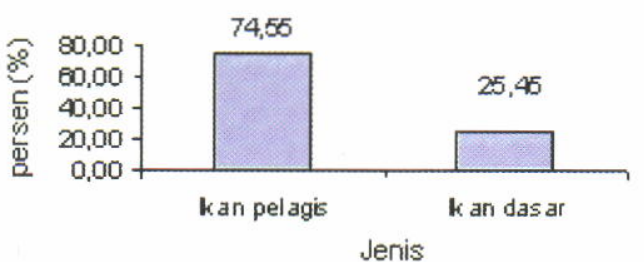

Gambar 8. Komposisi hasil tangkapan.

Figure 8. Catch composition. 


\section{Rerata berat kan dominan}

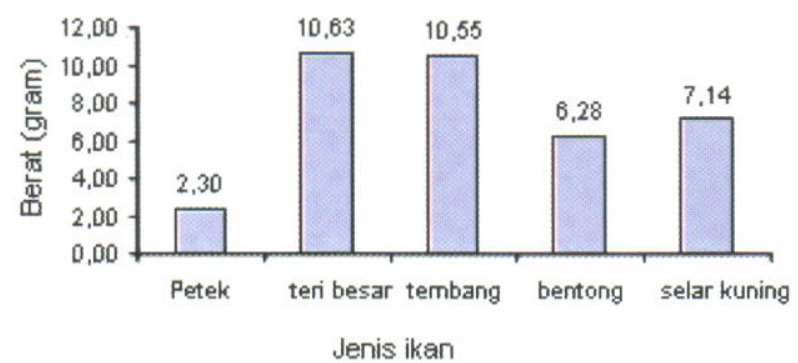

Gambar 9. Rata-rata bobot ikan dominan.

Figure 9. Average weight of dominant fish.

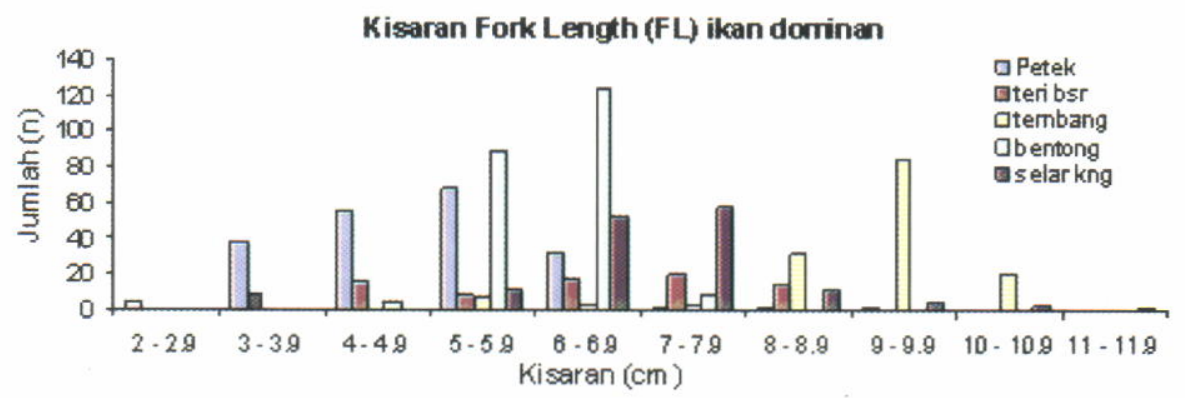

Gambar 10. Kisaran panjang cagak ikan dominant.

Figure 10. Fork length range of dominant fish.

Tabel 2. Kisaran fork length dan length of maturity ikan dominan Table 2. Fork length and length range of maturity of dominant fish

\begin{tabular}{lcccc}
\hline \multicolumn{1}{c}{$\begin{array}{c}\text { Jenis ikan/ } \\
\text { Species }\end{array}$} & $\begin{array}{c}\text { Jumlah/ } \\
\text { Number } \\
\text { (n) }\end{array}$ & $\begin{array}{c}\text { Fork length } \\
\text { (cm) }\end{array}$ & $\begin{array}{c}\text { Modus FL } \\
\text { (cm) }\end{array}$ & $\begin{array}{c}\text { Length of maturity } \\
\text { (cm) }\end{array}$ \\
\hline Teri (Stelephorus indicius) & 80 & $2-9$ & 8 & 12 \\
Petek (Leiognathus splendens) & 196 & $2-10$ & 6 & 9 \\
Tembang (Sardinella fimbriata) & 140 & $5-11$ & 10 & 14 \\
Selar kuning (Selaroides leptolepis) & 145 & $5-14$ & 8 & 23 \\
Bentong (Selar crumenopthalmus) & 226 & $4-8$ & 7 & 19 \\
\hline
\end{tabular}

Pengambilan contoh dilakukan terhadap spesies ikan pelagis yang dominan, ikan teri (Stelephorus indicius) 80 ekor dengan rata-rata bobot 10,63 g, kisaran fork length $2-9 \mathrm{~cm}$. Ikan petek (Leiognathus splendens) 196 ekor dengan rata-rata bobot 2,30 g, kisaran fork length 2-10 cm. Ikan tembang (Sardinella fimbriata) 145 ekor dengan rata-rata bobot 10,55 g, kisaran fork length $5-11 \mathrm{~cm}$. Ikan selar kuning (Selaroides leptolepis) 140 ekor dengan rata-rata bobot 7,14 g, kisaran fork length 5-14 cm. Ikan bentong (Selar crumenopthalmus) 226 ekor dengan rata-rata bobot $6,28 \mathrm{~g}$, kisaran fork length $4-8 \mathrm{~cm}$ (Gambar 9 dan 10).

Dari 5 jenis ikan dominan hasil tangkapan yang berhasil diukur (Tabel 2) dapat dilihat bahwa ukuran modus pada nilai fork length lebih kecil dari nilai length of maturity. Hal ini menandakan bahwa ukuran ikan dominan hasil tangkapan tersebut kecil dan belum layak tangkap.

\section{KESIMPULAN}

1. Intensitas cahaya lampu mercury 1.000 watt secara horisontal pada permukaan perairan mencapai $0,004 \mu \mathrm{mol} \mathrm{s}^{-1} \mathrm{~m}^{-2}$ pada jarak $10 \mathrm{~m}$ dari sumber cahaya dan secara vertikal pada sumber cahaya intensitas mencapai $0,002 \mu \mathrm{mol} \mathrm{s} \mathrm{s}^{-1} \mathrm{~m}^{-2}$ pada kedalaman $10 \mathrm{~m}$.

2. Intensitas cahaya 10 lampu petromak secara horisontal pada permukaan perairan mencapai $0,014 \mu \mathrm{mol} \mathrm{s}^{-1} \mathrm{~m}^{-2}$ pada jarak $6 \mathrm{~m}$ dari sumber 
cahaya dan secara vertikal pada sumber cahaya intensitas mencapai $0,024 \mu \mathrm{mol} \mathrm{s} \mathrm{s}^{-1} \mathrm{~m}^{-2}$ pada kedalaman $6 \mathrm{~m}$.

3. Kelompok ikan secara horisontal dari pusat cahaya terdeteksi pada jarak $38 \mathrm{~m}$ untuk lampu petromak (10 unit) dan $50 \mathrm{~m}$ untuk lampu mercury (1.000 watt).

4. Ukuran ikan didominansi ikan-ikan yang berukuran kecil (-70--50 db), diduga konsentrasi ikan ini berada pada wilayah transisi (transition area) perbatasan antara light zone dan dark zone dengan kekuatan intensitas cahaya kurang dari $0,01 \mu \mathrm{mol} \mathrm{s}^{-1} \mathrm{~m}^{-2}$.

\section{PERSANTUNAN}

Tulisan ini merupakan kontribusi dari kegiatan riset pengaruh intensitas cahaya terhadap pola pengelompokkan ikan pada alat tangkap yang menggunakan alat bantu cahaya di perairan utara Jawa, T. A. 2005, di Balai Riset Perikanan Laut-Muara Baru, Jakarta

\section{DAFTAR PUSTAKA}

Arimoto, T. 1999. Fish Behaviour for Improving Fish Capture Technology. Tokyo University of Fisheries. Japan. $55 \mathrm{pp}$.

Atmadja, S. B. 1994. Pengamatan hasil tangkapan jaring klitik dengan cahaya dan kemungkinan pengembangan pada perikanan skala kecil. Jurnal Penelitian Perikanan Laut. Badan Penelitian dan Pengembangan Pertanian. (87): p. 56-59.

Ayodhyoa. 1981. Metode Penangkapan Ikan. Yayasan Dewi Sri. Bogor. 90 pp.
Baskoro, M. S. 1999. Capture process of the floatedbamboo platform lift net with light attraction (bagan). Doctor Thessis. Graduate School of Fisheries. Tokyo Univ. of Fish. Japan 149 pp.

Baskoro, M. S., Sudirman, \& A. Purbayanto. 2004. Analisis hasil tangkapan dan keragaman spesies setiap waktu haulling pada bagan rambo di perairan Selat Makassar. Buletin PSP. Institut Pertanian Bogor. XIII (1): p. 16-33.

Carpenter, K. E. \& V. H. Niem. 1998, The living marine resources of the western central pacific. Species Identification Guide for Fishery Purposes. FAO. Rome.

Iskandar, M. D., I. W. Ronny, \& Indrajaya. 2004. Respon ikan terhadap cahaya: Studi kasus penangkapan ikan dengan menggunakan bagan motor di perairan Teluk Semangka, Lampung. Buletin PSP. Institut Pertanian Bogor. XIV (2): p. 76-87.

Puspito, G. 2006. Persamaan matematika untuk menentukan sudut kemiringan tudung lampu yang digunakan pada perikanan bagan. Prosiding Seminar Nasional Perikanan Tangkap. Fakultas Perikanan dan IImu Kelautan. Institut Pertanian Bogor. p. 197-210.

Subani, W. \& H. R. Barus. 1989. Alat penangkapan ikan dan udang laut di Indonesia. Jurnal Penelitian Perikanan Laut. No.50 (Special Edition). Balai Penelitian Perikanan Laut. Jakarta. 248 pp.

Sudirman. 2003. Analisis tingkah laku ikan untuk mewujudkan teknologi ramah lingkungan dalam proses penangkapan pada bagan rambo. Disertasi Program Pascasarjana. Institut Pertanian Bogor. $307 \mathrm{pp}$. 
